\title{
Hepatitis E Virus
}

\author{
German Advisory Committee Blood (Arbeitskreis Blut), Subgroup 'Assessment of Pathogens \\ Transmissible by Blood'
}

\section{Current Knowledge about the Pathogen}

\subsection{Characteristics of HEV}

Until the early 1980s it was believed that hepatitis A virus (HAV) was the only human hepatitis virus transmitted by contaminated drinking water and food. Using serologic tests for HAV, an investigation of a large water-borne outbreak of hepatitis in Kashmir/India in 1978 confirmed that an agent other than HAV was responsible [1]. Retrospective studies of a hepatitis outbreak in Delhi/India in 1955-1956 suggested that this agent, now known as hepatitis E virus (HEV), was not an emerging pathogen, but had been circulating for a long time [2]. HEV was later identified as the causative agent of various hepatitis outbreaks in Asia, Africa and Mexico [3].

Experimental evidence that a hepatitis virus other than HAV was transmitted via the faecal-oral route came from experiments performed by Balayan et al. [4] and Chauhan et al. [5]. In (self-)infection experiments, volunteers (immune to HAV and HBV) were orally infected with stool suspensions from patients with hepatitis A-like disease from Uzbekistan and Northern India (infection with a suspension from 9 patients who had developed jaundice [4]; infection with a $10 \%$ stool suspension from a patient from North India [5]). Current epidemiologic knowledge suggests that HEV genotype 1 was used in these experiments.

An analysis of stool samples from the infected volunteers identified spherical virus-like particles with a diameter of 27-30 nm and a density of $1.35 \mathrm{~g} / \mathrm{cm}^{3}$ in $\mathrm{CsCl}$ gradients [4]. Morphologic criteria suggested the tentative grouping of the virus in the family of Caliciviridae [4]. Immune electron microscopy using convalescent sera revealed virus-like particles in stool samples collected during the pre-clinical (27 days post infection (dpi)) until the post-clinical phase (45 dpi; onset of clinical symptoms approximately $36 \mathrm{dpi}$ ). Macaques orally infected with stool suspension collected in the acute phase of infection developed markers of hepatitis [4].

Chauhan et al. [5] were able to detect virus by HEV-specific PCR in serum approximately $22 \mathrm{dpi}$ and in stools $30 \mathrm{dpi}$; the first (unspecific) symptoms were observed $30 \mathrm{dpi}$ and jaundice approximately 38 dpi until 120 dpi. Alanine transaminase (ALT) levels started to rise $30 \mathrm{dpi}$, reaching maximum levels $46 \mathrm{dpi}$ and staying elevated up to $120 \mathrm{dpi}$. Antibodies against HEV were first detected $41 \mathrm{dpi}$. The infection experiments revealed that HEV was detectable in blood for 10-14 days and in stools for 1 week prior to the onset of symptoms of hepatitis.

Until 1990, the only diagnostic methods for HEV detection and differentiation from HAV had been immune electron microscopy and inoculation of primates [4]. In 1991, the HEV genome was cloned and sequenced, enabling the development of molecular and serologic detection methods [6]. Sequence analysis demonstrated significant differences between the genome organisation of caliciviruses and HEV. Therefore HEV was grouped as the only member into the genus Hepevirus in the newly established virus family of Hepeviridae [7].

$\mathrm{HEV}$ is a small, non-enveloped, icosahedral virus with a diameter of approximately $32-34 \mathrm{~nm}$. The capsid of the virus seems to be composed of a single capsid protein. The HEV genome is a singlestranded, positive-sense RNA molecule with a size of approximately $7.2 \mathrm{~kb}$ (fig. 1). The coding regions of the genome are flanked by short untranslated regions (UTR) with a poly-A tail at the 3'and an $\mathrm{m} 7 \mathrm{G}$-Cap at the 5 -end [8-10]. The genome codes for three overlapping open reading frames (ORF1-3; fig. 1). At the 3 '-end, ORF2 with a size of approximately $2 \mathrm{~kb}$, encodes the capsid protein that is required for the assembly of HEV particles, the binding to the host cell and the induction of neutralising antibodies. The approximately $5 \mathrm{~kb}$ long ORF1 is located at the 5 '-end of the genome and codes for several non-structural proteins involved in RNA replication: guanylyl and methyl transferases, helicase, RNA-dependent RNA polymerase and a papain-like protease. ORF3 encodes a small immunogenic phosphoprotein of 123 amino acids in length that interacts with cellular signalling proteins. ORF3, 372 bp long, overlaps with the first 331 bases of ORF2 and the 5 '-end of ORF1.

Phylogenetic analysis of HEV isolated from humans and a variety of animal species proposed a revision of the taxonomy of the Hepeviridae (table 1) [10-21]. Two recent publications suggested

\section{KARGER}

Fax +497614520714

\section{(c) 2015 S. Karger GmbH, Freiburg}

$1660-3796 / 15 / 0424-0247 \$ 39.50 / 0$
Prof. Dr. Rainer Seitz

Paul-Ehrlich-Institut

Bundesinstitut für Impfstoffe und biomedizinische Arzneimittel

Paul-Ehrlich-Straße 51-59, 63225 Langen, Germany

seira@pei.de 
Fig. 1. Genome structure and mRNA for the synthesis of structural (ORF2) and non-structural (ORF1 and ORF3) proteins [8-10]. The viral genome with a size of about $7.2 \mathrm{~kb}$ is methylated ( $7 \mathrm{G}$ cap) at the $5^{\prime}$ end and carries a poly-A sequence (AA) at the $3^{\prime}$ end. The $5^{\prime}$ - and $3^{\prime}$-end are flanked by non-coding regions (untranslated regions; UTR). ORF1 is translated from the genomic mRNA, encoding a polyprotein with a length of 1,693 amino acids. Computerassisted analysis of the sequence and comparison to other positive-strand RNA viruses identified four functional domains $(\mathrm{MT}=$ methyltransferase; Pro $=$ papain-like cysteine protease; $\mathrm{Hel}=$ helicase; $\mathrm{Pol}=$ RNA-dependent RNA polymerase). It is not yet completely clear which proteases are involved in the processing of the polyprotein. Two other motifs

( $\mathrm{X}$ and $\mathrm{Y}$ ) with unknown function have homologies to other RNA viruses. ORF2 and 3 are translated from a bicistronic subgenomic mRNA with a length of $2.2 \mathrm{~kb}$. ORF2 encodes the capsid protein with a length of 660 amino acids ( $74 \mathrm{kDa}$ unglycosylated and $88 \mathrm{kDa}$ glycosylated form) and ORF 3 codes for a phosphorylated protein with a length of 123 amino acids. The numbers indicate the positions (nucleotide $=$ NT) of the start and end of the corresponding sequences of the viral genome and the vertical bars the predicted hairpin structures of the genome. classifying the molecularly characterised HEV in different taxonomic genera $[14,15]$. In both publications, comparable relationships of different isolates were established by phylogenetic analyses. While Smith and co-authors [14] divide the Hepeviridae into two genera with four species in the genus Orthohepevirus, Johne and co-authors [15] suggest the classification into five genera (table 1).

In principle, the differentiation of human HEV follows the previous classification into four genotypes which at present are further sub-grouped into 24 genetic subtypes: genotype 1 (HEV-1, Burmese strain and Asian strains with 5 subtypes a-e), genotype 2 (HEV-2, isolate from Mexico and strains from Africa with 2 subtypes a and b), genotype 3 (HEV-3, isolates from patients with sporadic hepatitis in industrialised countries and from animals, e.g. pigs, deer and mongoose with 10 subtypes a-j) and genotype 4 (HEV-4, isolates from patients with sporadic hepatitis in Asia and from pigs with 7 subtypes a-g). Neutralisation of viruses in cell culture systems and cross-protection experiments in animals imply that HEV-1-4 form a single serotype [22-24].

\subsubsection{Stability of HEV}

The thermal stability of HEV has been investigated in cell culture systems using stool-derived HEV. Heat treatment at $45-50{ }^{\circ} \mathrm{C}$ for $1 \mathrm{~h}$ reduced the virus titres by a factor of 2 , and incubation at $56^{\circ} \mathrm{C}$ inactivated the virus completely [25]. Differences in heat stability were observed for different $\mathrm{HEV}$ isolates; however, all isolates investigated were sensitive to treatment at $60^{\circ} \mathrm{C}$. In contrast, HAV was inactivated only after heat treatment at $66^{\circ} \mathrm{C}$, with the conclusion that HEV was less heat stable than HAV [25]. Tanaka et al. [26] extended the studies on thermal stability of HEV with cell culture-adapted HEV. Heat treatment of HEV at $90{ }^{\circ} \mathrm{C}$ for $1 \mathrm{~min}$ or at $70^{\circ} \mathrm{C}$ for 10 min completely inactivated HEV. Furthermore, treatment of virus suspensions at $56^{\circ} \mathrm{C}$ for $30 \mathrm{~min}$ reduced virus titres significantly compared to an incubation at $25^{\circ} \mathrm{C}$. Virus derived from serum or from cell culture was resistant against treatment with detergents (5\% Tween 20 ) or lipid solvents (chloroform) [27].

\subsubsection{Inactivation of HEV in Pig Products}

Knowledge of the stability of HEV in food is of importance for a risk assessment on the transmission of HEV through the consumption of uncooked or insufficiently heated pork products. For such investigations, livers from pigs and wild boars with a high titre of HEV were used. After treatment of the suspensions with RNases, the integrity of the viral capsids can be tested by quantitative PCR. In control experiments, it was shown that heat treatment of virus particles made viral RNA accessible to RNases resulting in degradation of the RNA genome. Using an HEV-specific PCR, the amount of un-degraded viral RNA can be quantified [28]. Incubation of HEV-positive liver homogenates for different time periods showed that HEV RNA was detectable for up to 50 days of storage at $22^{\circ} \mathrm{C}$ or $37^{\circ} \mathrm{C}$, and for up to 70 days of incubation at $4{ }^{\circ} \mathrm{C}$. Treatment of samples at $56{ }^{\circ} \mathrm{C}$ for 30 min reduced the amount of RNA protected in virus particle by a factor of approximately $10^{3}$ [28].

In comparable experiments, that followed procedures for the production of food from pig livers, liver homogenates from HEVpositive pigs were incubated for 5,10 or $20 \mathrm{~min}$ at $62^{\circ} \mathrm{C}, 68^{\circ} \mathrm{C}$ or $71^{\circ} \mathrm{C}$, respectively. Pigs were orally infected with the different samples, and the infection was monitored by determining viral RNA in the faeces and by determining anti-HEV antibodies [29]. Complete inactivation of $\mathrm{HEV}$ was achieved only after incubation at $71{ }^{\circ} \mathrm{C}$ for $20 \mathrm{~min}$. These findings prove that $\mathrm{HEV}$ is relatively stable in food, and that either prolonged incubation at $70{ }^{\circ} \mathrm{C}$ or higher temperatures, are required to inactivate $\mathrm{HEV}$ completely. 
Table 1. Hepeviridae ${ }^{a}$ : classification, host range and experimental transmissibility of HEV

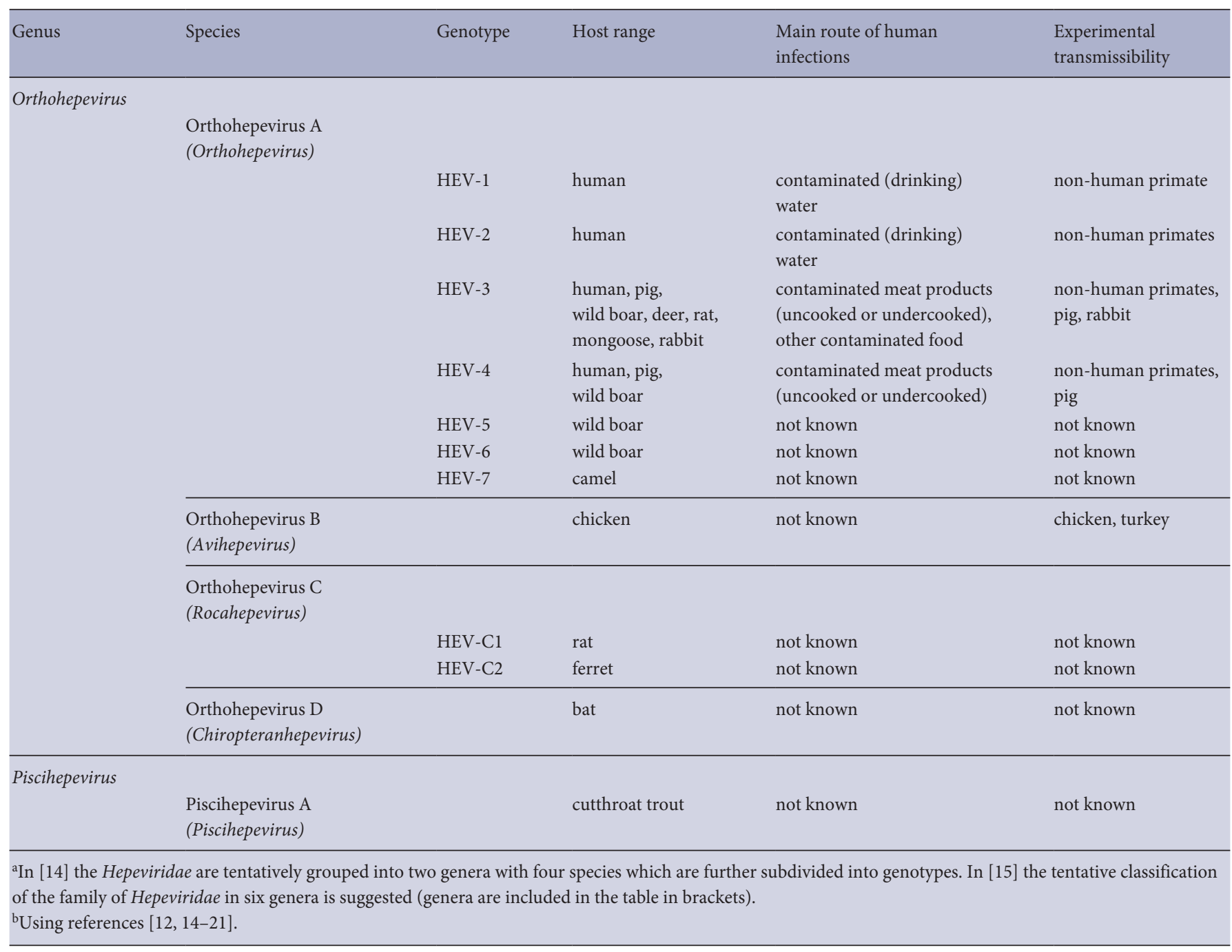

\subsection{Infection and Infectious Diseases}

Acute hepatitis $\mathrm{E}$ is comparable to acute hepatitis A and cannot be distinguished from each other based on clinical symptoms. According to our current knowledge, the course of infection with HEV-1 and HEV-2 appears to be different from that with HEV-3 and HEV-4. HEV-1 and HEV-2 are infectious for humans and various non-human primates, whereas the zoonotic agents HEV-3 and HEV-4 are able to infect humans as well as a variety of animal species (table 1, for a review see [30]). HEV-1 and HEV-2 are usually transmitted via contaminated water by the faecal-oral route, whereas the food-borne route transmits HEV-3 and HEV-4 by the consumption of uncooked or undercooked HEV-contaminated food [31]. As main sources of infection, HEV-contaminated livers from pig, wild boar and deer were identified [32]. Among the five human hepatitis virus families, HEV-3 and HEV -4 in the family of Hepeviridae are the only viruses with an animal reservoir.

Acute hepatitis caused by HEV-1 and HEV-2 is self-limiting. The case fatality rate in Asia appears to be higher for HEV-1 (0.54\%) than for hepatitis A (approximately 0.2\%) [33]. These data refer to clinical cases. However, considering the seroprevalence in HEV outbreaks, a lower case fatality rate of between 0.07 and $0.6 \%$ has been calculated [34]. The courses of infection with HEV-3 and HEV-4 are usually asymptomatic, and only sporadic cases of hepatitis E were reported.

It is assumed that HEV multiplies initially in the intestinal tract, and in the viraemic phase it is transported to the liver where virus replication takes place in the cytoplasm of hepatocytes. Virus is excreted via the bile into the stools where virus can be detected usually for 3-4 weeks. However, in some patients excretion of HEV in the stools for up to 120 days was demonstrated by PCR [35].

Experimental oral infection of volunteers with HEV revealed that viraemia was first detectable between 22 and $28 \mathrm{dpi}$, approximately 1 week before the onset of clinical symptoms $[4,5]$. First symptoms were observed between 30 and $36 \mathrm{dpi}$, coinciding with peak levels of ALT and the appearance of the first antibody response. Virus is shed in high amounts in the faeces, beginning in the late incubation phase up to the acute phase $[4,5]$. Histologically, focal necrosis and apoptosis of cells can be demonstrated in livers of patients with fulminant hepatitis [36]. It is unclear whether 
the virus induces the observed changes or the immune response against it, as only few inflammatory foci could be demonstrated in the liver [34, 36]. Comparable courses of HEV-1 infection were also observed in experimental infections of non-human primates. In such experiments, HEV RNA could be detected in the serum at approximately $10 \mathrm{dpi}$ [37-39].

Comparable with hepatitis A, an IgM response was detectable during the acute phase of an HEV infection around the time when clinical symptoms first occurred.

In high-endemic areas, a high percentage of pregnant women infected with HEV-1 develop fulminant hepatitis with a high mortality rate of up to $20 \%[2,34]$. Recent investigations in India showed that pregnant women infected with HEV-1 had an increased risk of developing fulminant hepatitis in comparison to non-pregnant women. Approximately two thirds of the diseased women had a premature delivery, and about half of them died from acute liver failure [2, 40]. However, in Egypt, an HEV-endemic area with a seroprevalence of up to $80 \%$, no differences could be observed in the courses of infection between pregnant and non-pregnant women [41]. It is unknown whether these differences can be explained by the circulation of different genotypes or HEV-1 strains with differences in pathogenesis [42]. In recent investigations, cytokines seem to play a significant role in the course of the HEV infection of pregnant women with fulminant hepatitis. Up to now, fulminant hepatitis $\mathrm{E}$ has been documented in pregnant women only for infections with genotype 1 viruses [43]. Analysis of the data showed a positive correlation of the elevation of the cytokine levels, the virus load and the negative outcome of pregnancy [44]. It should be noted that, so far, no differences in the course of HEV-3 infections or in the severity of symptoms of pregnant and non-pregnant women have been reported from regions like Europe or the USA where HEV-3 is prevalent [43]. Single cases of acute hepatitis, with elevated liver values, were diagnosed in pregnant women in France, the UK or Germany [45-47]. The course of infection was self-limiting and the new-borns were healthy. In two of the new-borns, (maternal) antibodies against HEV were detected, but no HEV infection $[45,47]$. These results might be explained by a lower pathogenicity of HEV-3 compared to $\mathrm{HEV}-1$ for pregnant women.

To facilitate a more detailed assessment of the pathologic potential of HEV-3 and HEV-4 for pregnant women, it could be investigated whether and to what extent HEV seroconversion occurs during pregnancy. Furthermore, in the case of a suspected HEV infection, acute hepatitis can be diagnosed by the determination of liver values. To what extent HEV-3 and HEV-4 infections are associated with spontaneous abortions or malformations could be investigated in suspicious cases by detection of HEV genome sequences.

In addition to hepatitis, neurologic disorders, acute pancreatitis, autoimmune symptoms and haematologic abnormalities were reported as a consequence of an HEV infection [48, 49].

In recent years, increasing numbers of $\mathrm{HEV}$ infections with a subclinical course have been reported, in particular in blood donors [50, 51]. As markers of infection, elevated transaminase levels may occur. Asymptomatic HEV infections can be diagnosed by the determination of HEV genome in the blood by nucleic acid testing (NAT) or the increase in HEV-specific IgM and IgG antibody titres [52].

In recent years, chronic hepatitis $\mathrm{E}$ (duration of viraemia longer than 3 months) has been observed in immunocompromised patients, e.g., organ transplant recipients [53-58], patients with haematologic tumours [59-62], patients after allogeneic haematopoietic stem cell transplantation and HIV-infected patients with low CD4 cell counts [63-66]. Furthermore, the immune response against $\mathrm{HEV}$ is often delayed in immunosuppressed patients. Therefore, when showing elevated liver values, such patients should be tested for HEV RNA. In an analysis of 85 organ transplant recipients with an HEV infection, chronic hepatitis $\mathrm{E}$ was observed in $65 \%$ of these patients, and $9 \%$ developed cirrhosis. In specific cases re-transplantation was necessary. Immunosuppression seems to be an important factor for the development of a chronic course of infection $[54,67]$. No evidence of a chronic course of HEV-1 infections was found in investigations of transplanted patients in HEV1-endemic regions [68]. So far, chronic courses of hepatitis E were only observed with HEV-3 and in one case with HEV-4 [53, 62].

Furthermore, HEV-3-induced hepatitis in particular is not always recognized. Retrospective studies on samples from patients suffering from liver-toxic effects due to medication showed that in some of these cases an HEV infection was discovered, suggesting that HEV was the cause of the symptoms $[69,70]$.

According to the Protection against Infection Act (Infektionsschutzgesetz; IfSG) implemented in 2001, hepatitis $\mathrm{E}$ is a notifiable disease in Germany. In $\$ 6$ IfSG the obligation to report a hepatitis E case and in $\$ 7$ IfSG laboratory-confirmed cases are regulated. According to the case definition by the Robert Koch Institute (RKI), a clinical case of hepatitis $\mathrm{E}$ is defined as the presence of at least one of the following four symptoms: fever, jaundice, considerably increased serum transaminases or abdominal pain. According to this case definition, the laboratory criteria for the diagnosis of an acute hepatitis $\mathrm{E}$ are the direct detection of viral nucleic acid in stools, serum or plasma by NAT methods such as PCR, or indirect detection of pathogens (IgM antibodies or significant rise in IgG titre in two consecutive serum samples).

\subsection{Epidemiology}

Serological investigations revealed that HEV occurs world-wide with partial regional differences in seroprevalence [71]. Whether differences in the sensitivity and specificity of the antibody test systems used for such studies are responsible for these differences has to be clarified. Epidemiologic studies have shown that HEV can be transmitted to humans via four main routes: i) through contaminated water (faecal-oral route) (HEV-1, HEV-2), ii) HEV-contaminated food of animal origin (HEV-3, HEV-4), iii) contaminated blood products or transplants and iv) vertically from mother to child. It is unclear to what extent sexual contacts pose a risk of infection. A recent study from the UK implied that, in comparison to the general population, men who have sex with men showed a 
Table 2. Detection of HEV genotypes $1-4$ in different countries*

\begin{tabular}{|c|c|c|c|c|c|}
\hline \multirow[t]{2}{*}{ Genotype } & \multicolumn{5}{|l|}{ Region } \\
\hline & Asia & Africa & America & Europe & Oceania \\
\hline 1 & $\begin{array}{l}\text { Bangladesh, Cambodia, } \\
\text { China, India, Japan, } \\
\text { Kyrgyzstan, Myanmar, } \\
\text { Nepal, Pakistan, } \\
\text { Uzbekistan, Vietnam }\end{array}$ & $\begin{array}{l}\text { Algeria, Central African } \\
\text { Republic, Chad, Djibouti, } \\
\text { Egypt, Ghana, Morocco, } \\
\text { Namibia, South Africa, } \\
\text { Sudan, Tunisia }\end{array}$ & $\begin{array}{l}\text { Cuba, Uruguay, } \\
\text { Venezuela or } \\
\text { associated with } \\
\text { travelling }\end{array}$ & $\begin{array}{l}\text { Southern Europe } e^{* * *} \text { or } \\
\text { associated with travelling }\end{array}$ & $\begin{array}{l}\text { no information } \\
\text { available }\end{array}$ \\
\hline \multicolumn{2}{|l|}{2} & $\begin{array}{l}\text { Central African Republic, } \\
\text { Chad, Namibia, Nigeria, } \\
\text { Sudan, Tunisia }\end{array}$ & Mexico & no information available & $\begin{array}{l}\text { no information } \\
\text { available }\end{array}$ \\
\hline 3 (worldwide ${ }^{* *}$ ) & $\begin{array}{l}\text { Cambodia, China, } \\
\text { India, Japan, Korea, } \\
\text { Kyrgyzstan, Taiwan, } \\
\text { Thailand }\end{array}$ & $\begin{array}{l}\text { Cameroon, Central } \\
\text { African Republic, Egypt, } \\
\text { Tunisia }\end{array}$ & $\begin{array}{l}\text { Argentina, Canada, } \\
\text { Mexico, Uruguay, USA } \\
\text { (South and North } \\
\text { America) }\end{array}$ & $\begin{array}{l}\text { Europe, Austria, France, } \\
\text { Germany, Greece, } \\
\text { Hungary, Italy, Russia, } \\
\text { Spain, the Netherlands, UK }\end{array}$ & $\begin{array}{l}\text { Australia, } \\
\text { New Zealand }\end{array}$ \\
\hline 4 & \multicolumn{2}{|l|}{$\begin{array}{l}\text { China, India, Indonesia, } \\
\text { Japan, Taiwan, Vietnam }\end{array}$} & $\begin{array}{l}\text { no information availa- } \\
\text { ble }\end{array}$ & $\begin{array}{l}\text { France, Germany, Italy, } \\
\text { Spain }\end{array}$ & $\begin{array}{l}\text { no information } \\
\text { available }\end{array}$ \\
\hline \multicolumn{6}{|c|}{$\begin{array}{l}{ }^{*} \text { Adapted from }[8,12,75-77] \text {. Listed are countries in which the respective HEV genotypes were determined. Serological investigations show that HEV infections } \\
\text { occur in further countries but their genotype is not known. } \\
{ }_{* *} \text { The detection of HEV-3 infections is closely related to the prevalence of HEV-3 and }-4 \text { in pig populations; however, there must be additional animal reservoirs } \\
\text { as cases of HEV-3 infections are described in countries in which consumption of pig products are forbidden. } \\
{ }^{* *} \text { The detection of HEV-1 in sewage suggest that the infections were acquired in Europe. }\end{array}$} \\
\hline
\end{tabular}

slightly elevated seroprevalence, whereas no difference regarding this group was reported from the USA [30, 72].

The faecal-oral route plays a crucial role, particularly in the transmission of HEV-1 and HEV-2 [4, 73]. While HEV-1 has led repeatedly to large outbreaks in a variety of Asian and African countries and sporadic outbreaks in Latin America (Venezuela and Cuba), HEV-2 seems to be less widespread. HEV-2 was identified for the first time in the mid-1980s in two outbreaks in Mexico and later also in cases of hepatitis in African countries like Nigeria, $\mathrm{Na}$ mibia and Chad. Besides HEV-2, HEV-1 is circulating in these African countries. Furthermore, reports of HEV-3 in African countries are increasing (table 2) [8, 12, 74-77].

HEV-1 and HEV-2 are human-specific and can be transmitted experimentally to non-human primates such as chimpanzees and macaques, but not to other species like pigs and rodents [78]. According to previous findings, infections with HEV-1 and HEV-2 in Europe were generally associated with stays in endemic areas [79, 80]. To what extent HEV-1 is circulating in different regions of Europe and whether individual HEV-1 hepatitis cases described as autochthonous infections were due to the circulation of this genotype needs to be further investigated [81].

The analysis of published data allowed the estimation of the prevalence and incidence of HEV-1 and HEV-2 infections in endemic regions of Asia and Africa [82]. In 2005, about 20 million infections were calculated world-wide, approximately 3 million of infected people developed symptoms of hepatitis, about 70,000 of these patients died, and in approximately 3,000 pregnant women the infection induced stillbirths. Corresponding estimates for infections with HEV-3 and HEV-4 could not be performed because the necessary data are unavailable.
After the first description of HEV in pigs [83, 84], increasing numbers of reports showed that sporadic HEV-caused hepatitis cases are observed in non-endemic areas, i.e. in industrialised countries, for which no connection with travel to classical endemic regions was evident. In these developed countries, people suffered from infections with genotypes 3 and 4 (table 2).

HEV-3 is observed world-wide and has been detected in Asia, America, Africa, Europe and Oceania, whereas infections with HEV -4 have been documented so far mainly in Asia (China, Japan, Vietnam, Indonesia and India) $[8,12,74]$. Recently, however, human infections with genotype 4 have been reported in Europe, showing slightly more severe clinical symptoms than infections with genotype $3[85,86]$, but a variant of genotype 3 with increased virulence has also been described in Japan [87].

Hepatitis E caused by HEV-3 and HEV-4 is classified as a zoonosis [16]. In industrialised countries, animals, pigs in particular, are considered a source of the infectious agent for humans. Seroepidemiological studies demonstrate a high prevalence of HEV in pig populations in almost all regions of the world [11]. While in Europe and the USA HEV - 3 is found in pigs, in China and Japan both HEV-3 and HEV-4 are prevalent [16,88-91]. Phylogenetic studies of these HEV isolates indicate high heterogeneity of the sequences of both genotypes. These findings enable the determination of the origin of the different virus isolates, their regional distribution as well as the follow-up of dissemination.

To what extent hygienic conditions in a region influence the prevalence of the different genotypes causing acute hepatitis $\mathrm{E}$ should be investigated further. Hepatitis E caused by genotypes 1 or 4 is observed in China [92]. Retrospective analysis of Chinese HEV isolates, collected between 1986 and 2011, showed an increas- 
Table 3. Notification of HEV infections in compliance with the IfSG*

\begin{tabular}{lcc}
\hline Year & Total & Acquired in Germany \\
\hline 2001 & 34 & $12(44 \%)$ \\
2002 & 17 & $7(41 \%)$ \\
2003 & 32 & $10(33 \%)$ \\
2004 & 53 & $21(40 \%)$ \\
2005 & 54 & $23(44 \%)$ \\
2006 & 52 & $24(44 \%)$ \\
2007 & 73 & $46(61 \%)$ \\
2008 & 104 & $70(69 \%)$ \\
2009 & 108 & $84(81 \%)$ \\
2010 & 221 & $166(73 \%)$ \\
2011 & 238 & $181(78 \%)$ \\
2012 & 387 & $298(79 \%)$ \\
2013 & 459 & $374(85 \%)$ \\
\hline \multirow{3}{*}{ ×Source: Robert Koch-Institute: SurvStat [100] as } \\
of September 22, 2014. \\
\hline
\end{tabular}

ing frequency of HEV transmission from pigs to humans, particularly of genotype 4 , while the number of infections with genotype 1 fell [93].

Experimental infection of non-human primates with HEV isolates from pigs and humans supports the hypothesis that hepatitis E, caused by genotypes 3 and 4 , is a zoonotic disease [11, 16]. In addition to pigs, HEV has been detected in various other species such as rats, dogs and birds (table 1). It is still unclear whether and to what extent these species play a role as source of HEV transmitted to humans.

Initial evidence that hepatitis E may be caused by consuming uncooked or insufficiently heated pork products arose from studies in Japan at the beginning of the 21st century [94]. In pig livers bought in grocery stores, HEV sequences could be detected by PCR that could be grouped to either genotype 3 or 4 . Sequence analysis revealed that these sequences were closely related to those of hepatitis patients who lived in the same region.

HEV RNA has been detected in wastewater in a variety of industrialised countries, such as Spain (Barcelona), France (Nancy) and the USA (Washington, DC). Both human and animal (pig) faeces are a likely source of contamination of the wastewater. It is unclear to what extent HEV can be transmitted by inadequately treated wastewater, which for example, is used for irrigation in industrialised countries. The detection of HEV in municipal sewage indicates that in countries where only sporadic HEV hepatitis occurs, the infection is often subclinical because no symptomatic HEV infections are observed concurrently [95]. Recent studies of wastewater in Switzerland, Italy and Spain show that, in addition to HEV-3, HEV-1 sequences can be detected. The extent to which contamination with HEV-1 is derived from faeces of travellers returning from HEV-1-endemic areas or whether this genotype is circulating in the area of the wastewater treatment plants is unclear [81].

HEV infections have been reported to be linked to the consumption of mussels and oysters; the detection of HEV RNA in mussels confirms the role of mussels as a vector $[96,97]$. Furthermore, HEV infections have been observed in individuals who pre- dominantly live as vegetarians, suggesting an additional transmission route. HEV was detected on vegetables, which was probably derived from HEV-contaminated water or manure [98].

Recording the number of hepatitis E cases in developed countries, such as Europe, Japan and the USA, provides only limited information on the prevalence of HEV infections in the population. The course of infection with HEV-3 or HEV-4 is predominantly asymptomatic. Reliable epidemiologic data on the prevalence of HEV can therefore only be collected by determining HEV-specific antibodies. In this respect, it should be considered that HEV is not always recognised as a cause of hepatitis.

The German Health Interview and Examination Survey for Adults (2008-2011; Deutscher Erwachsenen Gesundheitssurvey (DEGS)) enabled to estimate the prevalence of HEV infections in Germany [99]. More than 4,000 sera from adults aged 18-79 years were investigated using HEV-specific antibody tests. It could be shown that $16.8 \%$ of the samples were antibody-positive, with an increase in the antibody prevalence with age.

According to the IfSG, HEV infections that meet the criteria of the case definitions of the RKI have been notifiable in Germany since 2001. Since then the number of reported HEV cases have been rising continuously (table 3 [100]); this increase is mainly due to the reporting of autochthonous HEV cases. For some of the reported cases, it was possible to carry out further investigations [79]. HEV genome could be detected by PCR in 29 of the cases, and for 24 of these individuals HEV sequences could be generated and analysed phylogenetically. Sequencing of 9 samples proved that these infections had been imported; in 8 cases ( 7 cases from India, 1 from Ethiopia) genotype 1 was identified and in 1 case genotype 3 (USA). In 15 patients with an autochthonously acquired HEV infection, HEV-3 sequences were detected that were related to HEV sequences from pigs in Europe. The identification of genotype 4 in one autochthonous case was unexpected. Phylogenetic analysis showed a relationship to Japanese HEV-4 sequences [79]. Comparison of the number of HEV antibody-positive individuals with the number of reported hepatitis $\mathrm{E}$ cases suggests that only a small percentage of HEV-infected individuals in Germany develop hepatitis (table 3).

Molecular-epidemiologic studies suggest that HEV-4 is already circulating in European pig populations and that autochthonous human infections occur. The detection of autochthonous HEV-4 infection in Germany, Italy and France as well as the detection of HEV-4 in Belgian and Italian pigs provide evidence of local circulation of HEV-4 in Europe [101-104]. Phylogenetic analyses of French HEV-4 sequences suggest that HEV-4 was first introduced into France around the year 2000 [102, 105]. In addition, these analyses show that HEV-4 was repeatedly imported into Europe from HEV-4-endemic regions such as China and Japan [103, 106]. Exactly how HEV-4 was imported remains unknown. In addition to importing infected animals or contaminated foods, infected (asymptomatic) travellers might play a role.

It is of interest to learn more about the spread of HEV-4 in pig populations as well as of human infections in Europe including Germany, because HEV-4-infected patients might become more severely ill than HEV-3-infected individuals $[8,85,86,107]$. 


\subsubsection{Detection of HEV in Animals and Relevance for the Transmission to Humans}

In recent years a variety of animal species have been investigated for the presence of markers of HEV using molecular and serologic methods. In addition, it was investigated whether the viruses detected in animals were zoonotic agents, able to infect humans [11]. Besides the detection of HEV antibodies or viral sequences in domestic and feral pigs and deer, HEV-like viruses were detected in a variety of other mammalian species including rats, rabbits, dogs, cats, cattle, horses, sheep, goats and mongooses as well as in birds and fish ([14] table 1).

\subsubsection{HEV Infection in Swine}

In pigs of all age groups, HEV infections take an asymptomatic course. So far, only HEV-3 and HEV-4 have been demonstrated in pigs world-wide. Whether genotypes 1 and 2 can infect pigs was investigated in Thailand where HEV-1 and in Mexico where possibly HEV-2 are endemic. PCR was used to search for HEV-1 and HEV-2 sequences in porcine sera and faeces. Both investigations found only HEV -3 in pigs [108].

HEV -3 and HEV -4 isolated from pigs are closely related to the corresponding human HEV genotypes circulating in the respective regions. In Japan, both HEV-3 and HEV-4 were detected in domestic pigs and in wild boars $[17,91]$. Phylogenetic analysis of isolates showed that HEV-3 circulating in Japan can be grouped to different genetic subtypes. In addition to Japan-specific HEV-3 sequences, sub-genotype sequences could be determined that are closely related to European and American isolates [89]. Possibly these subtypes had been imported into Japan with European and American breeding pigs in the 1960s [85, 90].

In Japan and China HEV-3 as well as HEV-4 were detected, whereas in Europe and in the USA only HEV-3 were detectable in domestic and wild pigs [17, 109-114].

However, the detection of sequences closely related to Chinese HEV-4 in Belgian and Italian pigs implies that HEV-4 has been introduced to Europe from regions with a high HEV-4 prevalence and is spreading in different pig populations $[101,103,104]$. This hypothesis is supported by the detection of HEV-4 in French hepatitis patients who had consumed sausage (figatellu) containing raw liver $[115,116]$. The phylogenetic classification of HEV isolates from these patients to HEV-4 sequences from Chinese pigs suggests that HEV-4 has been introduced from China by infected animals, travellers returning from endemic areas or through contaminated feed [101, 117]. Further investigations have to elucidate to what extent HEV-4 has already become established in the European pig population $[101,103,104]$.

The prevalence of HEV in German domestic pig populations from 11 states was investigated using antibody screening tests. It was shown that HEV is widespread and the determined prevalence is comparable to that in pig populations in other European countries and the USA [118]. Out of 1,072 swine sera, $49.8 \%$ reacted in antibody screening tests. Additional analyses revealed that HEV-specific IgG could be detected in $78.1 \%$ of the livestock [119]. A comparable HEV antibody prevalence (68.1\%) was also determined in samples collected from pigs in Bavarian slaughterhouses, with about $7 \%$ of the sera being IgM-reactive [120]. The detection of isolated IgM suggests that the samples came from pigs that had been infected recently and thus may contain infectious virus, for example in the liver. In countries such as Japan, the USA, the UK and Germany, HEV was detected in pig liver or other pork products that were released for consumption and commercially available [17, 32, 121-124]. Furthermore, HEV transmission by figatellu was observed in France, and HEV was detected in sausage in Spain $[115,116,123]$. These findings further support the transmission of HEV by consumption of contaminated food.

\subsubsection{The Impact of Wild Boars as a Reservoir of HEV}

Serologic and molecular studies demonstrate that HEV is widespread in Eurasian wild boar (Sus scrofa) populations. Sequence analyses show that both HEV-3 and HEV-4 are circulating in China and Japan in wild boars, whereas so far only HEV-3 has been observed in Europe [110, 125, 126]. HEV-3 RNA was detected in hunted wild boars in the liver and/or in the bile, regardless of the age of the animals. This leads to the hypothesis that wild pigs can excrete virus for a long time and can therefore serve as a source of infection for domestic pigs and other species [110]. However, the role of virus excretion via faeces for the dissemination of HEV in wild boar populations, but also for its transmission to other susceptible animals like deer or domestic pigs, is unknown.

In a Japanese study, livers from wild boars were analysed by PCR for the presence of HEV genomes [17]. Phylogenetic analyses revealed the presence of HEV-3 and HEV-4 sequences which were closely related to human HEV-3 and HEV-4 sequences. Additional HEV sequences determined in wild boars were distantly related to the known HEV-1 to HEV-4 sequences and might therefore represent new HEV genotypes (HEV-5 and HEV-6) within the proposed genus Orthohepevirus (table 1) [14, 17, 85]. To what extent these putative new genotypes or additional closely related HEV are able to infect humans and other animal species should be investigated further [85].

\subsubsection{Detection of HEV in Rabbits}

Phylogenetic analysis of HEV sequences from rabbits in different countries (e.g. China, USA and France) showed that these are closely related to HEV-3, but might represent a distinct group within this genotype (table 1) [14, 18, 127-129]. It should be noted that all rabbit HEV (rbHEV) sequences have an insertion of $93 \mathrm{nu}-$ cleotides in ORF1 that is not present in HEV-3 of pigs and humans. Whether rbHEV can be grouped as a separate genotype remains to be determined. Transmission experiments showed that some pigs infected with rbHEV-3 developed viraemia and shed virus with faeces [19]. However, epidemiologic studies showed that no transmission of rbHEV to pigs took place under natural conditions [88]. Phylogenetic analyses of rbHEV and a human HEV isolate suggest that rbHEV is able to infect humans [127]. The extent to which the experimental transmission to cynomolgus macaques 
and the cultivation of rbHEV on human cells might be a further evidence of a zoonotic potential of these viruses needs to be clarified further, along with the question which role rbHEV plays in the infection of humans [130, 131].

\subsubsection{Detection of HEV in Rats}

The detection of antibodies to HEV in rats implies that rats might serve as vector for the transmission of HEV to humans or other animals like pigs. HEV-like sequences were detected in rats in Germany, which could be phylogenetically separated from genotypes HEV-1 to HEV-4 and therefore formed a separate group [132]. In further studies it was shown that comparable HEV sequences were detected in rats in the USA [133]. Phylogenetic sequence analysis of various rat isolates revealed that they have a high degree of variability, comparable to that of HEV-1 to HEV-4 [134]. Therefore it was suggested to group this rat HEV to the genus Orthohepevirus, species Orthohepevirus C (HEV-C1) or to the genus Rocavirus in the family of Hepeviridae (table 1) $[14,15]$. Experimental infection of rhesus monkeys with rat HEV was unsuccessful - indicating that rat HEV is not transmissible to primates [133]. Furthermore, it has been shown that rat HEV is not transmissible to pigs [19].

In this context it should be mentioned that serologic studies, using recombinant rat HEV or HEV-3-specific antigens, indicated that sera from forest workers preferentially reacted with rat HEV antigens and they might therefore have been exposed to rat HEV [135]. To what extent this assumption is supported by the observation that rat HEV (HEV-C1) is able to replicate in human cells has to be further investigated [136].

Investigations of rats in the USA revealed mostly HEV-3 sequences, but also sporadically rat HEV [137]. Furthermore, it was shown that rats in the vicinity of a pig farm in Japan were infected with HEV-3 that was phylogenetically closely related to the pig HEV-3 [138]. Experimental infections showed that rats could not be infected with HEV genotypes 1, 2 and 3; therefore it remains unknown whether there are HEV-3 variants able to infect humans and pigs as well as rats [16]. Further investigations will be necessary to elucidate the role of rats in the dissemination of HEV. Furthermore, it has to be clarified whether there are particular rat HEV variants that are able to infect humans.

\subsubsection{Detection of HEV in Horses}

In Egypt about 13\% of the horses investigated had antibodies against HEV. PCR enabled the amplification of HEV sequences and their phylogenetic analysis. Three sequences were closely related to Egyptian human genotype HEV-1 sequences [139]. Whether, and to what extent, horses might serve as a reservoir of HEV or whether horses can be sporadically infected with human HEV-1 needs further elucidation [20, 21].

\subsubsection{Avian HEV}

HEV has been reported in chickens with hepatitis splenomegaly syndrome in Australia and the USA [140, 141]. Genetic and serologic studies have shown that avian HEV (aHEV) is related to human HEV. The tropism of human and avian HEV for the liver raised the question of whether aHEV was able to infect humans. Rhesus monkeys could not be experimentally infected, indicating that aHEV is not infectious for humans either [16]. Phylogenetic studies led to the suggestion to group aHEV as distinct species Orthohepevirus B in the genus Orthohepevirus or as Avihepevirus within the family of Hepeviridae (table 1) [14, 15, 142, 143]. The question of whether avian HEV sequences might be further differentiated into distinct genotypes remains open [14].

\subsubsection{Other Not Previously Categorized HEV}

HEV sequences have been detected in African, Central American and European bats [20]. In the proposed classification, these viruses represent the distinct species Orthohepevirus D within the genus Orthohepevirus or the genus Chiropterahepevirus in the family of Hepeviridae $[14,15]$. Bat HEV show high sequence variability, comparable to that of human HEV genotypes. But there is no evidence of HEV transmission from bats to humans [20].

In the Netherlands it was possible to demonstrate HEV in ferrets. Phylogenetic analyses imply that ferret HEV should be grouped to the species Orthohepevirus $\mathrm{C}$ as genotypes HEV-C2 (ferret HEV) and HEV-C1 (rat HEV) [14, 144]. Recently, HEV sequences were determined in camels, which are phylogenetically distinct from all other published mammalian HEV sequences [145]. The relatively close relationship of the sequence to other members of the species Orthohepevirus A suggested to group the camel HEV as genotype HEV-7 within the Orthohepevirus B. The phylogenetic analysis of HEV-related sequences identified in cutthroat trout led to the proposal to establish a distinct species Piscihepevirus A within the new genus Piscihepevirus [14, 21].

\subsection{Detection Methods and Their Significance}

\subsubsection{Direct Virus Detection}

For the direct detection of infectious virus, inoculation of virus suspensions into either experimental animals or into cell cultures is used. Initially, the diagnosis of HEV was performed by infection of non-human primates that are susceptible to HEV genotypes 1-4. After detection of genotypes 3 and 4 in pigs, human HEV -3 and HEV -4 could be inoculated into pigs, and the course of the infection was monitored by determining the virus in faeces or antibodies in serum. A comprehensive search for cell culture systems was initiated in which HEV could be propagated. The establishment of human cell lines (A549, No. RCB0098, RIKEN BRC Cell Bank, Tsukuba, Japan, and 196 PLC/PRF5, hepatocarcinoma cell line, ATCC No. CRL-8024, American Type Culture Collection, Manassas, VA, USA) supporting the growth of high titres of HEV have recently been reported [26, 27, 85, 146]. These cell culture systems should facilitate studies on the replication of $\mathrm{HEV}$, the search for inhibitors of virus replication and the development of antiviral substances. Furthermore, these culture cells are expected to be suitable for systematic studies on the stability of HEV and the evaluation of inactivation and elimination proce- 
dures such as those used in the production of biopharmaceuticals. Recently it was shown that these cell cultures enabled the isolation of HEV from serum and stools of patients as well as from faeces, serum and livers from pigs, wild boars and other species [147]. It should be examined if cell cultures can be used routinely for diagnostics. In other cell culture systems derived from human or porcine hepatocytes, HEV could not be propagated successfully to high titres [148].

\subsubsection{Detection of HEV Genome}

Detection of viral RNA in patient samples confirms an acute or chronic HEV infection. NAT systems were developed for the detection of HEV in blood, serum, plasma, stool and tissue samples. Sequence analysis of HEV isolates showed that there is a variety of genetic HEV variants. Thus the sensitivity and specificity of the PCR are dependent on primers and probes as well as on the genome sequence investigated [149]. 20 laboratories from 10 countries participated in a study in which a panel of 24 human plasma samples was distributed ( 2 of which were HEV RNA-negative and $22 \mathrm{HEV}$ RNA-positive including genotypes $3 \mathrm{a}, 3 \mathrm{~b}, 3 \mathrm{f}$ and $4 \mathrm{c}$ ) [150]. To determine the sensitivity and specificity of NAT systems (19 laboratories used in-house tests, 1 laboratory used a commercial test), HEV RNA-positive samples were diluted in HEV-negative plasma. The analysis of the results showed high specificity of all tests used in the laboratories. However, wide differences in test sensitivity were found in this study and in other investigations $[150,151]$. In the majority of tests the sensitivity varied by a factor of between 100 and 1,000, regardless of the geno- or sub-genotype investigated. The differences observed in the tests suggest that well-characterised reference materials have to be provided to laboratories and test developers to standardise the detection and genome quantification systems. A first standard preparation containing a defined amount of HEV-3a genome equivalents was developed for the WHO under the management of the PEI [152]. Reference preparations for additional HEV genotypes are currently under development.

\subsubsection{Serologic Test Systems for the Detection of HEV Infection}

Serologic methods are used for the diagnosis of acute or past HEV infections. An HEV infection is likely with the presence of anti-HEV IgM and distinct clinical symptoms of hepatitis. The serologic results have to be confirmed by a rise of IgG antibody titres in a second sample collected $8-10$ days later. In about $90 \%$ of acute HEV infections, IgM antibodies can be detected 1-4 weeks after the onset of clinical symptoms. About 3 months after onset of disease, IgM antibodies are generally no longer detectable [77]. An increase in the antibody titre against HEV antigens is observed at about the same time as the peak of transaminases [77, 153].

The serologic determination of an HEV infection is usually performed by ELISA tests and confirmed by immunoblot. Genetically engineered peptides derived from ORF2 and ORF3 of genotypes 1 or 2 serve as target antigens [154]. Commercial antibody detection systems are available for the detection of IgG and IgM antibodies.
Several studies have shown that there is strong cross-reactivity between HEV genotypes 1-4. Therefore it is widely accepted that human HEV can be grouped into a single serotype. Studies of antibody reactivity in sera from individuals infected with different HEV genotypes by using peptides derived from different HEV genotypes imply a limitation of the grouping of human HEV in a single serotype [154, 155].

Investigations on the reactivity of human sera in commercial HEV antibody detection systems showed differences in the sensitivity of these test systems [71]. Using different test formats, it was shown that the reactivity of sera from British patients varied depending on the test system $[156,157]$. Comparable differences in reactivity in ELISA and immunoblotting were observed when sera from individuals with an HEV-1 or HEV-3 infection were investigated [158]. An analysis of Korean sera in assay systems using HEV-1 or HEV-4 antigens revealed differences in reactivity in the test systems [159]. Varying reactivity of IgM and IgG antibodies against HEV antigens were also determined when different antibody detection systems were used [160, 161].

Recently, differences in the diagnostic sensitivity of the assays were also determined when German or Swiss sera were investigated with commercial HEV antibody detection systems [124, 162]. Therefore, depending on the detection system used, differences in the seroprevalence of HEV may be determined that might be partially due to unpredictable numbers of false-negative or false-positive reactions.

Therefore it appears necessary to validate antibody test systems in respect to sensitivity and specificity for the detection of antibodies induced by the infection with different HEV (e.g. genotypes or sub-genotypes) circulating in a given region. Improvement or modification of test systems seems to be a pre-condition for more reliable test results. As a precautionary measure, several ELISA tests showing a high rate of false-negative results were withdrawn from the market and replaced by new tests [163].

\subsubsection{Determination of HEV Antigens}

Antigen detection systems are used for the diagnosis of acute or persistent virus infections. In various publications, the applicability of antigen detection systems for the detection of viraemic patients and blood donors as well as for the follow-up of infections of experimental animals were investigated [164-168]. A relatively good correlation between the results of antigen detection systems and the NAT results were observed in hepatitis cases in India [164, 167]. However, a lower ratio of the correlation of NAT and antigen tests was observed in comparative studies of HEV-positive blood donors in Germany. These differences could be due to the fact that, on the one hand, acute HEV infections were studied in an endemic area with a high prevalence of genotype 1 and, on the other hand, HEV-3-infected, asymptomatic blood donors in Germany [165, 167]. Experimental infection of macaques with HEV-1 and HEV-4 showed that both genotypes were detected by the antigen test [168]. To what extent these or improved antigen detection systems are suitable for the detection of viraemic individuals, particularly of blood donors, needs further investigation. 


\section{Blood and Plasma Donors}

\subsection{Prevalence and Incidence in Blood Donor Populations}

The determination of HEV-specific antibodies enables an estimation of the prevalence of HEV in the general population or specific subpopulations, such as blood and plasma donors. In a seroprevalence study, the RKI determined an HEV seroprevalence of $16.8 \%$ in the age group of $18-79$ years [99].

Studies on the prevalence of HEV infections in blood donors determined different antibody prevalences. In the first German multicentre study, $0.5 \%$ of the donations reacted in antibody detection systems [169]. After improving the antibody detection systems, antibody prevalences of $5.9 \%, 6.8 \%$ or $15.5 \%$ were obtained in more recent studies [170-172]. Taking into account that diverse antibody detection systems had been used, the HEV antibody prevalence in the general population and in blood donors was comparable [173]. A variety of studies confirmed that the detection of antibodies against HEV in blood donor collectives was affected by the antibody detection systems used [174].

About 10 years ago, Japan reported HEV RNA-positive blood donations from healthy donors for the first time [50]. Retrospective studies of donations with elevated transaminases (study period 1991-2006) revealed an invariant incidence of HEV infection in Japanese blood donors [175]. Furthermore, it was not unexpected that genotypes 3 and 4 were detectable in the HEV RNA-positive donations in Japan.

A study of plasma donations of German, Swedish and American donors showed that $0.012 \%$ of Swedish and $0.022 \%$ of German donations were HEV RNA-positive, whereas no HEV RNA could be detected in American plasma donations [176]. In another approach more than 90,000 plasma donations in Germany were investigated for the presence of HEV RNA [177]. Testing was carried out on pooled samples from healthy blood donors. The extrapolation of the results allowed an estimation of the proportion of positive donations. The calculated amount of $0.015 \% \mathrm{HEV}$-positive donations was comparable to the results obtained by Baylis et al. [176].

An additional study of German blood donors revealed a higher percentage $(0.08 \%)$ of HEV RNA-positive donations [171]. To what extent these differences in the German donor population might be based on the selection of donors or on test systems with differences in sensitivity should be further investigated.

As expected from the epidemiologic distribution of genotypes in Germany, in both studies only HEV-3 sequences were determined that were related to sequences from either domestic pigs or wild boars [176, 177]. Studies of British HEV RNA-positive plasma donations gave comparable results [178]. These results show that plasma donors have a risk of acquiring an HEV infection and might be viraemic at the time of donation.

HEV genomes could be detected by PCR in plasma pools for fractionation from Europe, North America, the Middle East and Asia [179]. Eight out of 75 pools were positive for HEV sequences; pools of European and American donations contained genotype 3 and Asian pools genotype 4 [179].
There are only a few reports on the prevalence of HEV in blood donors in high-endemic areas (HEV-1, HEV-2). A retrospective study of transfusion recipients suggested that in HEV-1-endemic areas HEV could be transmitted by transfusion [180]. A similar conclusion was drawn in another study in which it was shown that after transfusion, some recipients had markers of HEV infections [181]. In Egypt, a country with a high HEV antibody prevalence of up to $80 \%$ in the rural population, 2/760 donations were HEV RNA-positive (0.26\%) [182]. However, there was no confirmation of the HEV genotype. In a study of blood donations in China 30 out of 44,816 donations $(0.07 \%)$ were HEV RNA-positive. In 13 donations the genotype 4 and in 17 donations the genotype 1 was demonstrated [183].

In an extensive study in the Netherlands, the prevalence and incidence of HEV in blood donors were investigated [174]. About a quarter of the donors were seropositive for HEV. Younger donors ( $<30$ years) showed a lower seroprevalence, and an age-dependent increase in HEV antibody positivity was observed. In 17 of $\sim 45,000$ donations, HEV-3 was detected. Retrospective studies of HEVpositive donors allowed the estimation of the incidence in the Netherlands which was calculated at $1.1 \%$ per donor year.

On the basis of seroconversion in repeat donors the incidence of HEV infections could be estimated in blood donors in Germany [172]. According to these estimates, the annual incidence rate in blood donors was $0.35 \%$. The differences in the HEV incidence in Germany and the Netherlands might be due to the use of antibody detection systems with different sensitivity [174]. However, the different incidence could also be explained by a higher risk of exposure of Dutch compared to German blood donors, as Dutch blood donors showed a higher prevalence of antibodies [170-174].

\subsubsection{Estimation of Morbidity}

The estimated HEV incidence of $0.35 \%$ among repeat donors corresponds well with the estimated HEV incidence of $0.39 \%$ $(0.36-0.42 \%)$ in a representative sample of the general population [99]. It can therefore be estimated for Germany that 150,000300,000 individuals become infected with HEV per year. Comparable incidences were reported for the USA $(0.7 \%)$, the UK $(0.2 \%)$ and the Netherlands $(1.1 \%)[172,174,184]$. It is difficult to calculate the morbidity due to HEV infections because of an assumed under-reporting of clinical cases. Comparing the number of reported hepatitis E cases with the number of estimated HEV infections, one can assume that in Germany at least $0.2-0.3 \%$ of $\mathrm{HEV}$ infected individuals developed hepatitis E [100].

\subsection{Definition of Exclusion Criteria}

In Germany, the exclusion criteria for blood donors are defined by the guidelines of the Federal Medical Association (Bundesärztekammer) and the PEI [185]. Individuals who have or have had infectious hepatitis of unknown aetiology are excluded permanently from donating blood. In these guidelines, HEV infection is not explicitly mentioned. In the case of an acute or suspected hepatitis $\mathrm{E}$, the donor must be deferred from donation. Up to now no 
human-to-human HEV-3 and HEV-4 transmissions have been observed through social contacts. Therefore, it should be discussed whether donors should be deferred in case hepatitis E was suspected in a close contact person. Past hepatitis E and/or the detection of anti-HEV IgG antibodies are not criteria for exclusion. This recommendation corresponds to the procedure established for donors who have recovered from a HAV infection [186].

\subsection{Donor Testing and Significance}

In principle, testing of donors for HEV genome by PCR or anti$\mathrm{HEV}$ antibodies (IgM as an early marker of infection) is possible. An analysis of donations showed that HEV RNA can be present without detectable IgM or increased transaminase levels in serum. Therefore, IgM determination is not a suitable tool for the exclusion of viraemic blood donors.

\subsection{Donor Interviews}

In accordance with the guidelines of the Federal Medical Association and the PEI, potential donors must be interviewed before donating blood to determine whether they have a history of hepatitis. Since HEV infections are usually asymptomatic, specific questions regarding an HEV infection do not appear to be meaningful. A history of hepatitis $\mathrm{E}$ alone is not a criterion for general donor exclusion. The majority of travellers returning from HEV-1- and HEV-2-endemic areas will be deferred on account of traveling in malaria-endemic areas.

\subsection{Donor Information and Counselling}

Since no specific testing of donations for HEV markers is performed, HEV-specific donor information is not indicated. In the case of evidence of hepatitis of unknown origin, an HEV infection should be confirmed or ruled out using serologic and/or molecular methods.

\section{Recipients}

\subsection{Prevalence and Incidence of Blood-Associated Infections and Infectious Diseases in Recipient Populations}

Investigations in blood donor populations and in the general population in Germany indicate a comparable HEV antibody prevalence. Therefore, one can assume that the prevalence in the recipient populations corresponds to that in the general population, as has been described in other European countries.

Studies in Japan and Europe, where HEV-3 and/or HEV-4 are endemic, show that in a few cases HEV has been transmitted by blood transfusion, inducing hepatitis E. Retrospective surveys of transfused patients with elevated transaminase levels or those who developed fulminant hepatitis revealed that part of the recipients had been infected by transfusion of an HEV-contaminated donation [59, 70, 181, 187-192]. Recently, in a recipient of a pooled platelet concentrate an HEV infection was diagnosed in Germany, which was identified through a look-back to be related to a donor who developed an acute HEV infection after donation. It is noteworthy that the recipient did develop signs of hepatitis. An additional HEV transmission by a platelet concentrate was reported in Germany [193]; the donor was healthy at the time of apheresis and showed no signs of an infection. The recipient of the platelet concentrate developed a chronic HEV infection. Two years prior to the HEV infection he had received an allogeneic stem cell transplant and was treated with immunosuppressive drugs because of a graftversus-host reaction. Treatment of the patient with ribavarin and reduction of immunosuppression induced a decrease of the virus load. However, a flare of the graft-versus-host reaction was observed, and the patient died 8 months after the transfusion [194].

In several studies it was shown that haemodialysis patients have an increased risk of acquiring an HEV infection [190, 195]. Usually, it is unknown whether the infection was related to the administration of blood products or had been acquired by other means. Only a few studies of haemophilia patients have been reported in the literature [196, 197]; no risk of acquiring an HEV infection by clotting factors became evident in any of these studies. However, an increased prevalence of antibodies was observed in a Japanese study of elderly haemophilia patients who had been treated with non-virus-inactivated clotting factors [198]. Furthermore, it was reported from Canada and France recently that HEV can be transmitted by SD-treated plasma [199, 200]. HEV was also transmitted by amotosalen-inactivated plasma in France, which indicates that treatment of plasma with photoactive substances is not able to sufficiently inactivate HEV [201].

In recent years increasing numbers of reports have been published on HEV infection and disease progression in transplant recipients and immunocompromised patients [53, 60, 62, 202, 203]. However, only few reports demonstrated that an infection had been caused by the transplanted organ or by transfusion $[53,57$, $203,204]$. For most of the transplant recipients who developed hepatitis E, the infection could not be directly related to the transplantation. In this respect it has to be assumed that immunosuppression enhances the risk of acquiring an infection with HEV.

\subsection{Immune Status (Resistance, Immunity, Immune Response, Age, Exogenous Factors)}

At present, there are no specific investigations concerning antibody prevalence or incidence of HEV infections in recipients of blood and blood products in Germany. However, one can assume that this prevalence or incidence corresponds with the prevalence in the general population as well as in the blood and plasma donor populations. Previous findings imply that persons with a past HEV infection are protected against another infection with HEV. To 
what extent immunosuppressed or HIV-infected patients have an enhanced risk to acquire an HEV infection is not clear, because comparative studies of immunocompetent and immunocompromised individuals are missing. However, it was shown that immunosuppressed patients or those infected with HIV have an increased risk of developing hepatitis E [205]. Recent investigations of transplanted patients that were HEV antibody-positive before transplantation imply that these antibodies provide limited protection against re-infection. It might be speculated that the height of the antibody titre plays a significant role in the protection against an HEV infection [206]. Although recent studies failed to find a higher prevalence of HEV infections in HIV-infected patients, an increasing number of persistent HEV infections in these patients have been reported $[203,207]$. In transplant recipients a high percentage of HEV infections can take a chronic course [53, 67, 202, 208]. Chronic hepatitis caused by HEV-3 infection was observed mainly in immunosuppressed organ transplant recipients, but also in HIV-infected patients and in those with haematologic diseases. Recently, a chronic HEV-4 infection was reported from China [62]. There are no reports yet of chronic hepatitis after an infection with HEV-1 or HEV-2 $[68,153]$.

\subsection{Severity and Course of the Disease}

So far, there are no investigations that would provide information about the incidence of HEV transmissions through blood products causing clinically silent courses of infection. Due to the frequency of HEV-RNA-positive blood donations, it can be assumed that HEV is transmitted to recipients. Presumably such infections remain undetected because of the mostly asymptomatic course of infection. A case of transfusion-associated transmission without pathological findings was reported in Germany and was discovered because the donor developed hepatitis after donation. Up to now, cases of HEV hepatitis due to transfusion of HEV-contaminated blood components were documented in Europe only in 3 patients receiving chemotherapy [191-194]. Two of the patients with hepatitis recovered without antiviral treatment with ribavarin and the third one identified in Germany developed a chronic HEV infection [191-193]. Chronic infections have been observed in transplanted, immunocompromised and HIV-infected patients. In some of the cases the symptoms were assigned to another cause like side-effects of drugs or graft-versus-host reactions [53, 67, 153, 203, 204] (see also 3.2). However, it cannot be excluded that additional factors have an influence on the course of infection and the severity of the disease. Therefore, further investigations are necessary to elucidate whether the severity of the disease is caused by the HEV infection.

\subsection{Therapy and Prophylaxis}

Up to now, HEV hepatitis has only been treated in patients after organ or stem cell transplantation who developed a chronic HEV infection [67, 203]. Reducing the dose of immunosuppressive drugs resulted in some of the patients in the normalization of liver enzyme values as well as in a decline in viraemia and shedding of virus in stool. However, it has to be considered that modification of the chemotherapy regimen might be associated with a rise in the graft-versus-host reaction [194]. Acute and chronic HEV infections were successfully treated with ribavarin or in some cases with a combination of ribavarin and pegylated IFN- $\alpha$ [203, 204, 209, 210]. Modification of the regimen of chemotherapy or treatment with antiviral substances (ribavarin, interferon) led to recovery in the majority of the patients $[67,203,204]$.

The first HEV vaccine (Hecolin; Xiamen Innovax Biotech, Xiamen, China) was approved by the Chinese State Food and Drug Administration (SFDA) in December 2011. In a large phase III trial, the safety and efficacy of this vaccine have been investigated $[211,212]$. The vaccine is based on a $26 \mathrm{kDa}$ HEV-1 ORF2 fragment expressed in Escherichia coli, forming 23-nm virus-like particles. The vaccine has proved to be effective and well tolerated. Taking into account that in China most hepatitis $\mathrm{E}$ cases have been caused by genotype 4 in the past years, it can be assumed that this vaccine induces cross-genotype immunity.

Another vaccine, derived from a $56 \mathrm{kDa}$ ORF2 fragment expressed in the baculovirus system in insect cells, was investigated in Nepal in cooperation with American partners who immunised members of the armed forces. The vaccine was also found to be immunogenic and resulted in vaccinated persons in a high level of protection against infection with HEV-1 prevalent in Nepal [213]. Additional experimental vaccines based on recombinant $\mathrm{HEV}$ proteins or HEV DNA coding for ORF2 are being investigated in various model systems for their immunogenicity and cross-reactivity [24, 214-216]. Up to now no licenced vaccines are available in Europe. To what extent vaccination of patients with a risk of developing chronic hepatitis E appears to be appropriate should be discussed as soon as licenced HEV vaccines are available.

\subsection{Transmissibility}

Retrospective studies in regions in which HEV is endemic suggest that HEV can be transmitted by blood transfusion [180, 217]. Transfusion-associated HEV transmission has been reported from Saudi Arabia, a country where HEV-1 is endemic [181]. First reports on transfusion-associated HEV infections in Japan that is not classified as an HEV-endemic area were published at about the same time $[188,190]$. Transmission of HEV through therapeutic plasma was documented, but not through the concentrate of red blood cells from the same donor [188].

Transfusion-associated HEV transmissions have also been reported in Europe, a region in which acute hepatitis $\mathrm{E}$ is observed only sporadically. Increased awareness and the availability of sensitive serological and molecular detection methods demonstrate increasing numbers of transfusion-associated HEV infections. In the UK, an erythrocyte concentrate containing a small amount of donor plasma infected a patient treated with cytostatic drugs. A pooled platelet preparation using platelets from the same donor did 
not infect the recipient [191]. A child in France suffering from a kidney tumour who was treated with cytostatic drugs was infected with HEV through an erythrocyte concentrate [192]. Both donors in the UK and in France acquired their HEV infections locally.

The HEV transmissions observed in France and the UK increased the awareness in these countries. In an extensive study in England, more than 220,000 blood donations were tested by PCR for HEV RNA, and 79 viraemic donors were identified [218]. The viraemic donations were used for the preparation of 129 blood components, of which 62 were transfused. The follow-up of 43 recipients of such products showed that 18 recipients had markers of an HEV infection. The 8 recipients who were not immunosuppressed or treated only with low doses of immunosuppressive drugs recovered. An additional 10 patients were treated with medium or high doses of immunosuppressive drugs. As has been shown in other studies, immunocompromised patients had a delayed immune response or failed to seroconvert. Four of the $10 \mathrm{pa}-$ tients ( 2 with medium and high immunosuppression) died during the study period, but the deaths could not be attributed to the HEV infection. In 3 patients ( 1 patient with medium and 2 patients with high immunosuppression), reduction of the dose of the immunosuppressive drug cured the hepatitis. One patient with high immunosuppression was additionally treated with ribavirin. In this investigation transmissions of $\mathrm{HEV}$ were observed with erythrocytes (4/16 transfusions), pooled platelets (4/10) and platelets obtained by apheresis $(7 / 7)$, by fresh frozen plasma (2/14) and by a preparation of pooled granulocytes.

Transmissions by labile blood products were increasingly reported in France that were usually discovered by the detection of elevated liver markers [200]. The majority of the reported cases involved immunocompromised patients. HEV transmissions occurred in 2 cases by erythrocyte and platelet concentrates obtained by apheresis and in 5 cases by plasma ( 2 transmissions each by SD and quarantine plasma and plasma treated with amotosalen). Additional reports on the transmission of HEV by plasma treated with amotosalen plasma were reported from France [201].

Two transmissions of HEV by a platelet concentrate were identified in Germany. The transfusion of a pooled platelet concentrate resulted in an HEV infection, and the recipient developed a chronic hepatitis [193]. A further HEV transmission was detected in the context of a look-back procedure. The female donor of a platelet preparation, which was part of a pooled platelet concentrate, suffered from hepatitis $\mathrm{E}$ after the donation. The recipient was inconspicuous but the infection could be confirmed by the seroconversion. All donors were HEV-RNA-positive at the time of donation but showed no enhancement of transaminase levels.

From these few cases of HEV transmission, it can be concluded that the virus can be transmitted by non-virus-inactivated blood components. It is likely that this is possible in particular by cell-free virus in plasma during the donor's viraemic phase (about 20-50 dpi).

The documented transfusion-associated transmissions of HEV in Europe that either caused (chronic) hepatitis or were asymptomatic raised the question of whether all donations should be tested for HEV virus genome [187, 193, 218-220]. To what extent general testing of donations for HEV genome appears to be practicable and useful should be discussed against the background of the findings that chronic cases of hepatitis $\mathrm{E}$ are observed in principle only in immunosuppressed patients and HEV infections in immunocompetent individuals are in most cases asymptomatic and are cured spontaneously.

\subsection{Frequency of Administration, Type and Amount of Blood Products}

The few reported cases of HEV infection by blood components like erythrocyte or platelet concentrates as well as SD plasma do not enable a risk assessment. Plasma donated in the viraemic phase is considered as source of infection by cellular blood components [191-193, 199]. Other retrospective studies of organ transplant recipients who were multi-transfused and developed hepatitis $\mathrm{E}$ after transplantation showed that none of the blood donors was HEVinfected; and therefore donations could be ruled out as source of HEV infection [221].

\section{Blood Products}

\subsection{Load of the Starting Material and Test Methods}

The detection of HEV in blood and plasma donations can be performed by NAT. Investigations of plasma pools and blood donations with HEV-specific PCR showed that about $0.012-0.08 \%$ of blood or plasma donations in Germany contained HEV RNA [171, 176].

Investigations of plasma donations in the UK and Sweden gave comparable results $[176,178]$. The HEV RNA titres are often low (up to $10^{5}$ genome equivalents (ge) $/ \mathrm{ml}$ blood), but titres of up to $10^{7} \mathrm{ge} / \mathrm{ml}$ have been detected in a few blood donations. In large plasma pools (approximately 10,000 donations) virus loads of $10^{3}$ ge/ml can be observed $[176,179]$.

\subsection{Methods for Removal and Inactivation of the Infectious Agent}

A risk of transmission of HEV by blood components cannot generally be excluded. The efficiency of virus inactivation procedures that had been developed for plasma and cellular blood products (like treatment with amotosalen, derivatives of psoralen, riboflavin or methylene blue) do not appear to be safe. In a study, riboflavin showed only limited reduction of the virus load by factor of 100-1,000 [222].

$\mathrm{HEV}$ as a non-enveloped virus is not sensitive to treatment with detergents. Therefore the SD inactivation procedure of plasma or treatment with amotosalen is considered as ineffective [199-201].

Production of plasma derivatives includes methods for virus inactivation (such as heat treatment and/or treatment with detergents and lipid solvents) or virus removal (for example, filtration, 
protein precipitation or chromatography). It can be assumed that these procedures that have been shown to be effective against a variety of enveloped and non-enveloped viruses are also effective against $\mathrm{HEV}$.

\subsection{Feasibility and Validation of Procedures for Elimination/ Inactivation of the Infectious Agents}

Studies on the inactivation of HEV are available only to a limited extent. The recently established cell culture systems have to be further evaluated for their suitability of the production processes. In previous years the feline calicivirus (FeCV) was widely used as a model virus for the validation of virus inactivation procedures. FeCV can be effectively inactivated at $60^{\circ} \mathrm{C}$ (Groener, unpublished results; Bluemel, unpublished results). To what extent FeCV reflects the stability of HEV is questionable. It is also not yet clear whether or not the data obtained for HAV can be transferred to HEV. Cell culture systems that would allow a validation of the effectiveness of current procedures for HEV reduction will therefore be of great interest for the risk assessment of plasma products.

In preliminary studies, HEV appeared to be more thermolabile than HAV [25]. However, neither kinetics of inactivation nor the influence of stabilisers such as those used in the production of clotting factors have been extensively investigated. Studies by a Japanese manufacturer of plasma products suggest a certain temperature resistance of HEV [223]. In these experiments the inactivation of HEV seemed to be limited to a factor of $2 \log 10$ during pasteurisation of albumin $\left(60^{\circ} \mathrm{C}, 10 \mathrm{~h}\right)$. In the presence of stabilisers, dryheat treatment of clotting factors failed to completely inactivate HEV. Furthermore, alcohol precipitation steps used in the production of albumin reduced HEV titres only by a factor of $0-2.3 \log 10$ [224]. It is still unclear to what extent these results are reproducible or relevant for the validation of production procedures used by other manufacturers of plasma derivatives. Currently, several manufacturers of plasma products are investigating the suitability of cell culture systems for the validation of the efficacy of virus inactivation procedures, but no results have been submitted yet.

The stability of HEV at low $\mathrm{pH}$ ( $\mathrm{pH}$ 3.7-4.2), like those used in the production of antibody preparations is not known. Adoption of results obtained in inactivation studies using other non-enveloped viruses might only be possible with restrictions. HAV and animal parvoviruses are stable under these low $\mathrm{pH}$ conditions. It is not known to what extent data obtained regarding the reduction of HAV titres also applies to HEV.

It can be assumed that filtration processes (i.e., virus filter, nanofilter) effectively remove HEV from the product if it is shown that smaller viruses such as HAV or parvoviruses are effectively eliminated from the product. Such filters are often used in the production of factor IX (FIX) and in part in the production of immunoglobulins or highly purified FVIII. Filtration of complex coagulation factors is only possible by using medium pore size filters $(35-50 \mathrm{~nm})$ that presumably will not remove HEV effectively [223] (PEI, unpublished data).
In investigations of several plasma derivatives currently used in Germany, no HEV RNA could be detected in final products [225]. This could be explained by a complete or partial removal of virus particles present in the starting plasma pools that predominantly contain low titres of HEV.

\section{Assessment}

HEV infections of immunocompetent persons are usually asymptomatic and self-limiting. For a long time it had been assumed that HEV is endemic only in developing countries and involved in hepatitis outbreaks. In developing countries, two humanspecific HEV genotypes 1 and 2 were identified which are transmitted mainly through contaminated water. In these countries, severe hepatitis cases and deaths were observed particularly in pregnant women. The HEV genotypes 1 and 2 seem to be only occasionally imported by travellers to Europe. In recent years, it has become apparent that HEV is also widely distributed in industrialised countries. In these countries the HEV genotypes 3 and 4, which are classified as zoonotic agents, are transmitted to humans by contaminated food, especially by insufficiently heated pork. Sporadically more severe disease progression is observed in Europe.

Cases of hepatitis of unknown cause are not always tested for HEV. Therefore, it is currently difficult to estimate the role of HEV in such cases. The recently described cases of acute hepatitis in pregnant women in Europe, caused by HEV-3, recovered, and the new-born babies were healthy. In immunosuppressed patients, HEV-3 infection can take a chronic course; some cases have been associated with fibrosis and cirrhosis. In the German asymptomatic donor population, viraemic blood donations were observed with a frequency of $1: 1,240$ to $1: 4,500$. Donor selection with respect to $\mathrm{HEV}$-specific risk factors is not possible because the exposure to HEV seems to be widespread.

For the screening of blood donations for HEV, the method of choice is at present NAT. Antibody tests are inappropriate because viraemic donations are rarely antibody-positive. Suitable NAT systems have been developed in the last few years, and CE-certified tests are commercially available.

Although plasma pools may be contaminated with HEV, plasma derivatives are $\mathrm{HEV}$-safe for the treatment of patients according to available virological and epidemiologic findings. In the manufacturing process of plasma derivatives, production steps are established that effectively inactivate or remove non-enveloped viruses such as HAV. This observation justifies the assumption that these procedures will also be effective against HEV. However, as soon as adequate cell culture systems for the determination of infectivity are available, critical virus inactivation or elimination steps in the production process of plasma derivatives (especially heat treatment) have to be evaluated for their effectiveness against HEV. This would enable an extended risk assessment of plasma derivatives with respect to HEV to be performed.

HEV can be transmitted by blood components (e.g. erythrocyte and platelet concentrates and therapeutic plasma). Because the 
manufacturing process of SD-treated plasma does not inactivate $\mathrm{HEV}$, the European Pharmacopoeia requires testing of plasma pools using HEV NAT from 2015.

The currently available methods for the inactivation of pathogens in blood components do not seem to safely inactivate HEV. In principle, testing of all donated blood is possible, but this is not considered necessary because of the limited virulence of HEV for immunocompetent recipients of blood components. However, $\mathrm{HEV}$ infections seem to pose a risk for heavily immunosuppressed patients according to previous findings, especially for patients following allogeneic stem cell and organ transplantation. In these patients, the course of HEV infections can often become chronic. These patients would potentially benefit from a provision of HEV RNA-negative blood components. However, at present the causal relationship of HEV infection and severe disease progression in immunosuppressed patients is not yet sufficiently documented. According to current knowledge, a HEV-NAT with a sensitivity of approximately $100 \mathrm{IU} / \mathrm{ml}$ would be necessary to achieve a considerable reduction of HEV transmissions. Research is needed regarding the extent to which an introduction of NAT for the screening of blood donations could reduce the risk of infection and disease in immunosuppressed transplant recipients. Regardless of the risk of transmission of HEV by blood components, it is recommended to continuously monitor immunocompromised patients, especially transplant recipients, with regard to HEV infections.

This paper was completed on September 19, 2014 and approved by the German Advisory Committee Blood (Arbeitskreis Blut) on October 8, 2014. It was compiled by the members of the subgroup 'Assessment of Pathogens Transmissible by Blood' of the German Advisory Committee Blood (Arbeitskreis Blut):

Prof. Dr. Georg Pauli

Prof. Dr. Martin Aepfelbacher

Dr. Ursula Bauerfeind

PD Dr. Dr. Johannes Blümel

Prof. Dr. Reinhard Burger

Prof. Dr. Barbara Gärtner

Dr. Albrecht Gröner

Prof. Dr. Lutz Gürtler

Dr. Margarethe Heiden

Prof. Dr. Martin Hildebrandt

Prof. Dr. Dr. Bernd Jansen

Dr. Ruth Offergeld

Dr. Uwe Schlenkrich

Dr. Volkmar Schottstedt

Prof. Dr. Rainer Seitz

Dr. Johanna Strobel

Dr. Hannelore Willkommen

supported by Dr. Sally A. Baylis (PEI)

\section{References}

1 Khuroo MS: Study of an epidemic of non-A, non-B hepatitis: possibility of another human hepatitis virus distinct from post-transfusion non-A, non-B type. Am J Med 1980;68:818-823.

2 Khuroo MS: Discovery of hepatitis E: the epidemic non-A, non-B hepatitis 30 years down the memory lane. Virus Res 2011;161:3-14.

$>$ Kmush B, Wierzba T, Krain L, Nelson K, Labrique AB: Epidemiology of hepatitis $\mathrm{E}$ in low- and middle-income countries of Asia and Africa. Semin Liver Dis 2013;33:15-29.

4 Balayan MS, Andjaparidze AG, Savinskaya SS, et al: Evidence for a virus in non-A, non-B hepatitis transmitted via the fecal-oral route. Intervirology 1983;20:23-31.

5 Chauhan A, Jameel S, Dilawari JB, Chawla YK, Kaur U, Ganguly NK: Hepatitis E virus transmission to a volunteer. Lancet 1993;341:149-150.

6 Reyes GR, Yarbough PO, Tam AW, et al: Hepatitis E virus (HEV): the novel agent responsible for enterically transmitted non-A, non-B hepatitis. Gastroenterol Jpn 1991;26(suppl 3):142-147.

7 Emerson SU, Anderson D, Arankalle A, et al: Hepevirus; in Fauquet CM, Mayo MA, Maniloff J, Desselberger U, Ball LA (eds): Virus Taxonomy: VIIIth report of the ICTV. London, Elsevier/Academic Press, 2004, pp 851-855.

8 Okamoto H: Genetic variability and evolution of hepatitis E virus. Virus Res 2007;127:216-228.

9 Ahmad I, Holla RP, Jameel S: Molecular virology of hepatitis E virus. Virus Res 2011;161:47-58.

10 Cao D, Meng XJ: Molecular biology and replication of hepatitis E virus. Emerg Microbes Infect 2012;1:e17.

11 Pavio N, Meng XJ, Renou C: Zoonotic hepatitis E: animal reservoirs and emerging risks. Vet Res 2010;41:46.

12 Lu L, Li C, Hagedorn CH: Phylogenetic analysis of global hepatitis E virus sequences: genetic diversity, subtypes and zoonosis. Rev Med Virol 2006;16:5-36.
Meng XJ: Recent advances in hepatitis E virus. J Viral Hepat 2010;17:153-161.

14 Smith DB, Simmonds P, Jameel S, et al: Consensus proposals for classification of the family Hepeviridae. J Gen Virol 2014;95:2223-2232.

15 Johne R, Dremsek P, Reetz J, Heckel G, Hess M, Ulrich RG: Hepeviridae: an expanding family of vertebrate viruses. Infect Genet Evol 2014;27C:212-229.

16 Meng XJ: Hepatitis E virus: animal reservoirs and zoonotic risk. Vet Microbiol 2010;140:256-265.

17 Takahashi M, Nishizawa T, Nagashima S, et al: Molecular characterization of a novel hepatitis E virus (HEV) strain obtained from a wild boar in Japan that is highly divergent from the previously recognized HEV strains. Virus Res 2014;180:59-69.

18 Lhomme S, Dubois M, Abravanel F, et al: Risk of zoonotic transmission of HEV from rabbits. J Clin Virol 2013;58:357-362.

19 Cossaboom CM, Córdoba L, Sanford BJ, et al: Crossspecies infection of pigs with a novel rabbit, but not rat, strain of hepatitis $\mathrm{E}$ virus isolated in the United States. J Gen Virol 2012;93:1687-1695.

20 Drexler JF, Seelen A, Corman VM, et al: Bats worldwide carry hepatitis E-related viruses that form a putative novel genus within the family Hepeviridae. J Virol 2012;86:9134-9147.

21 Batts W, Yun S, Hedrick R, Winton J: A novel member of the family Hepeviridae from cutthroat trout (Oncorhynchus clarkii). Virus Res 2011;158:116-123.

22 Huang W, Zhang H, Harrison TJ, Lang S, Huang G, Wang Y: Cross-protection of hepatitis $\mathrm{E}$ virus genotypes 1 and 4 in rhesus macaques. Med Virol 2008;80:824-832. 23 Sanford BJ, Dryman BA, Huang YW, Feagins AR, Leroith T, Meng XJ: Prior infection of pigs with a genotype 3 swine hepatitis E virus (HEV) protects against subsequent challenges with homologous and heterologous genotypes 3 and 4 human HEV. Virus Res 2011; 159:17-22.
24 Sanford BJ, Opriessnig T, Kenney SP, Dryman BA, Córdoba L, Meng XJ: Assessment of the cross-protective capability of recombinant capsid proteins derived from pig, rat, and avian hepatitis E viruses (HEV) against challenge with a genotype $3 \mathrm{HEV}$ in pigs. Vaccine 2012;30:6249-6255.

25 Emerson SU, Arankalle VA, Purcell RH: Thermal stability of hepatitis E virus. J Infect Dis 2005; 192:930-933.

26 Tanaka T, Takahashi M, Kusano E, Okamoto H: Development and evaluation of an efficient cell-culture system for hepatitis E virus. J Gen Virol 2007;88:903-911.

27 Takahashi M, Tanaka T, Takahashi H: Hepatitis E virus (HEV) strains in serum samples can replicate efficiently in cultured cells despite the coexistence of HEV antibodies: characterization of HEV virions in blood circulation. J Clin Microbiol 2010;48:1112-1125.

28 Schielke A, Filter M, Appel B, Johne R: Thermal stability of hepatitis E virus assessed by a molecular biological approach. Virol J 2011;8:487.

29 Barnaud E, Sophie Rogée S, Garry P, Rose N, Pavio N: Thermal inactivation of infectious hepatitis $\mathrm{E}$ virus in experimentally contaminated food. Appl Environ Microbiol 2012;278:5153.

30 Hoofnagle JH, Nelson KE, Purcell RH: Hepatitis E. N Eng J Med 2012;367:1237-1244.

31 Van der Poel WH: Food and environmental routes of hepatitis E virus transmission. Curr Opin Virol 2014;4: 91-96.

32 Teo CG: Much meat, much malady: changing perceptions of the epidemiology of hepatitis E. Clin Microbiol Infect 2010;16:24-32.

33 World Health Organization, Department of Communicable Disease Surveillance and Response: Hepatitis E - WHO/CDS/CRS/EDC/2001.12. Geneva, World Health Organization, 2001 www.who.int/csr/disease/ hepatitis/HepatitisE_whocdscsredc2001_12.pdf(last accessed May 7, 2015). 
34 Aggarwal R: Clinical presentation of hepatitis E. Virus Res 2011;161:15-22.

35 Nanda SK, Ansari IH, Acharya SK, Jameel S, Panda SK: Protracted viremia during acute sporadic hepatitis E virus infection. Gastroenterology 1995;108:225-230.

36 Agrawal V, Goel A, Rawat A, Naik S, Aggarwal R: Histological and immunohistochemical features in fatal acute fulminant hepatitis E. Indian J Pathol Microbiol 2012;55:22-27.

37 Aggarwal R: Hepatitis E: Historical, contemporary and future perspectives. J Gastroenterol Hepatol 2011;26: $72-82$.

38 Purcell RH, Emerson SU: Animal models of hepatitis A and E. ILAR J 2001;42:161-177.

39 Zhang J, Ge SX, Huang GY, et al: Evaluation of antibody-based and nucleic acid-based assays for diagnosis of hepatitis $\mathrm{E}$ virus infection in a rhesus monkey model. J Med Virol 2003;71:518-526.

40 Borkakoti J, Hazam RK, Mohammad A, Kumar A, Kar P: Does high viral load of hepatitis E virus influence the severity and prognosis of acute liver failure during pregnancy? J Med Virol 2013;85:620-626.

41 Stoszek SK, Abdel-Hamid M, Saleh DA, et al: High prevalence of hepatitis $\mathrm{E}$ antibodies in pregnant Egyptian women. Trans R Soc Trop Med Hyg 2006; 100:95-101

42 Blackard JT, Rouster SD, Nady S, et al: Genotypic characterization of symptomatic hepatitis E virus (HEV) infections in Egypt. J Clin Virol 2009;46:140-144.

43 Navaneethan U, Al Mohajer M, Shata MT: Hepatitis E and pregnancy: understanding the pathogenesis. Liver Int 2008;28:1190-1199.

44 Kumar A, Devi SG, Kar P, et al: Association of cytokines in hepatitis $\mathrm{E}$ with pregnancy outcome. $\mathrm{Cy}$ tokine 2014;65:95-104.

45 Anty R, Ollier L, Péron JM, et al: First case report of an acute genotype 3 hepatitis $\mathrm{E}$ infected pregnant woman living in South-Eastern France. J Clin Virol 2012;54: 76-78.

46 Andersson MI, Hughes J, Gordon FH, Ijaz S, Donat M: Of pigs and pregnancy. Lancet 2008;372:1192.

-47 Tabatabai J, Wenzel JJ, Soboletzki M, Flux D, Navid $\mathrm{MH}$, Schnitzler P: First case report of an acute hepatitis E subgenotype $3 \mathrm{c}$ infection during pregnancy in Germany. J Clin Virol 2014;61:170-172.

48 Cheung MC, Maguire J, Carey I, Wendon J, Agarwal $\mathrm{K}$ : Review of the neurological manifestations of hepatitis E infection. Ann Hepatol 2012;11:618-622.

49 Aggarwal R: Hepatitis E: clinical presentation in disease-endemic areas and diagnosis. Semin Liver Dis 2013;33:30-40.

50 Mitsui T, Tsukamoto Y, Suzuki S, et al: Serological and molecular studies on subclinical hepatitis E virus infection using periodic serum samples obtained from healthy individuals. J Med Virol 2005;76:526-533.

51 Gotanda Y, Iwata A, Ohnuma H, et al: Ongoing subclinical infection of hepatitis $\mathrm{E}$ virus among blood donors with an elevated alanine aminotransferase level in Japan. J Med Virol 2007;79:734-742.

52 Adlhoch C, Kaiser M, Pauli G, Koch J, Meisel H: Indigenous hepatitis $\mathrm{E}$ virus infection of a plasma donor in Germany. Vox Sang 2009;97:303-308.

53 Zhou X, de Man RA, de Knegt RJ, Metselaar HJ, Peppelenbosch MP, Pan Q: Epidemiology and manage ment of chronic hepatitis $\mathrm{E}$ infection in solid organ transplantation: a comprehensive literature review. Rev Med Virol 2013;23:295-304.

54 Kamar N, Garrouste C, Haagsma EB, et al: Factors associated with chronic hepatitis in patients with hepatitis $\mathrm{E}$ virus infection who have received solid organ transplants. Gastroenterology 2011;140:1481-1489.

55 Haagsma EB, van den Berg AP, Porte RJ, et a: Chronic hepatitis $\mathrm{E}$ virus infection in liver transplant recipients. Liver Transpl 2008;14:547-553.
6 Halac U, Béland K, Lapierre P, et al: Chronic hepatitis E infection in children with liver transplantation. Gut 2012;61:579-603.

57 Schlosser B, Stein A, Neuhaus R, et al: Liver transplant from a donor with occult HEV infection induced chronic hepatitis and cirrhosis in the recipient. J Hepatol 2012;56:500-502.

58 Riezebos-Brilman A, Puchhammer-Stöckl E, van der Weide HY, et al: Chronic hepatitis $\mathrm{E}$ infection in lung transplant recipients. J Heart Lung Transplant 2013; 32:341-346.

59 Tamura A, Shimizu YK, Tanaka T, et al: Persistent infection of hepatitis E virus transmitted by blood transfusion in a patient with T-cell lymphoma. Hepatol Res 2007;37:113-120.

60 Ollier L, Tieulie N, Sanderson F, et al: Chronic hepatitis after hepatitis $\mathrm{E}$ virus infection in a patient with non-Hodgkin lymphoma taking rituximab. Ann Intern Med 2009;150:430-431.

61 Tavitian S, Péron JM, Huynh A, et al: Hepatitis E virus excretion can be prolonged in patients with hematological malignancies. J Clin Virol 2010;49:141-144.

62 Geng Y, Zhang H, Huang W, et al: Persistent hepatitis E virus genotype 4 infection in a child with acute lymphoblastic leukemia. Hepat Mon 2014;14:e15618.

63 Dalton HR, Keane FE, Bendall R, Mathew J, Ijaz S: Treatment of chronic hepatitis $\mathrm{E}$ in a patient with HIV infection. Ann Intern Med 2011;155:479-480.

64 Versluis J, Pas SD, Agteresch HJ, et al: Hepatitis E virus: an underestimated opportunistic pathogen in recipients of allogeneic hematopoietic stem cell transplantation. Blood 2013;122:1079-1086.

65 Keane F, Gompels M, Bendall R, et al: Hepatitis E virus coinfection in patients with HIV infection. HIV Med 2012;13:83-88.

66 Jagjit Singh GK, Ijaz S, Rockwood N, et al: Chronic hepatitis $\mathrm{E}$ as a cause for cryptogenic cirrhosis in HIV. J Infect 2013;66:103-106.

67 Unzueta A: Hepatitis E infection in liver transplant recipients. Liver Transpl 2014;20:15-24.

68 Naik A, Gupta N, Goel D, Ippagunta SK, Sharma RK, Aggarwal R: Lack of evidence of hepatitis E virus infection among renal transplant recipients in a disease-endemic area. J Viral Hepat 2013;20:e138-e140.

69 Davern TJ, Chalasani N, Fontana RJ, et al; Drug-In duced Liver Injury Network (DILIN): Acute hepatitis $\mathrm{E}$ infection accounts for some cases of suspected druginduced liver injury. Gastroenterology 2011;141:16651672.e1-9.

70 Haïm-Boukobza S, Ferey MP, Vétillard AL, et al: Transfusion-transmitted hepatitis $\mathrm{E}$ in a misleading context of autoimmunity and drug-induced toxicity. J Hepatol 2012;57:1374-1378.

71 Echevarría JM: Light and darkness: prevalence of hepatitis $\mathrm{E}$ virus infection among the general population. Scientifica 2014;2014:481016.

72 Payne BA, Medhi M, Ijaz S, et al: Hepatitis E virus seroprevalence among men who have sex with men, United Kingdom. Emerg Infect Dis 2013;19:333-335.

73 Chandra NS, Sharma A, Malhotra B, Rai RR: Dynamics of HEV viremia, fecal shedding and its relationship with transaminases and antibody response in patients with sporadic acute hepatitis E. Virol J 2010;7:213.

74 Pelosi E, Clarke I: Hepatitis E: a complex and global disease. Emerg Health Threats J 2008;1:e8

75 Kim JH, Nelson KE, Panzner U, Kasture Y, Labrique AB, Wierzba TF: A systematic review of the epidemiology of hepatitis E virus in Africa. BMC Infect Dis 2014; 14:308.

76 Echevarría JM, González JE, Lewis-Ximenez LL, et al: Hepatitis E virus infection in Latin America: a review. J Med Virol 2013;85:1037-1045.

77 Aggarwal R, Jameel S: Hepatitis E. Hepatology 2011; 54:2218-2226.
8 Krawczynski K, Meng XJ, Rybczynska J: Pathogenetic elements of hepatitis E and animal models of HEV infection. Virus Res 2011;161:78-83.

79 Wichmann O, Schimanski S, Koch J, et al: Phylogenetic and case-control study on hepatitis E virus infection in Germany. J Infect Dis 2008;198:1732-1741.

80 Fogeda M, Avellón A, Cilla CG, Echevarría JM: Im ported and autochthonous hepatitis E virus strains in Spain. J Med Virol 2009;81:1743-1749.

81 Masclaux FG, Hotz P, Friedli D, Savova-Bianchi D, Oppliger A: High occurrence of hepatitis E virus in samples from wastewater treatment plants in Switzerland and comparison with other enteric viruses. Water Res 2013;47:5101-5109.

82 Rein DB, Stevens GA, Theaker J, Whittenborn JS, Wiersma ST: The global burden of hepatitis E virus genotypes 1 and 2 in 2005. Hepatology 2012;55:988997.

83 Meng XJ, Purcell RH, Halbur PG, et al: A novel viru in swine is closely related to the human hepatitis $\mathrm{E}$ virus. Proc Natl Acad Sci U S A 1997;94:9860-9865.

84 Feagins AR, Opriessnig T, Guenette DK, Halbur PG, Meng XJ: Detection and characterization of infectious hepatitis $\mathrm{E}$ virus from commercial pig livers sold in local grocery stores in the USA. J Gen Virol 2007;88: 912-917.

85 Takahashi M, Okamoto H: Features of hepatitis E virus infection in humans and animals in Japan. Hepatol Res 2014;44:43-58.

86 Jeblaoui A, Haim-Boukobza S, Marchadier E, Mokhtari C, Roque-Afonso AM: Genotype 4 hepatitis $\mathrm{E}$ virus in France: an autochthonous infection with a more severe presentation. Clin Infect Dis 2013;57:e122-126.

87 Takahashi K, Okamoto H, Abe N, et al: Virulent strain of hepatitis E virus genotype 3, Japan. Emerg Infect Dis 2009; 15:704-709.

88 Geng Y, Zhang H, Li J, et al: Comparison of hepatitis E virus genotypes from rabbits and pigs in the same geographic area: no evidence of natural cross-species transmission between the two animals. Infect Genet Evol 2013;13:304-309.

89 Nakano T, Okano H, Kobayashi M, et al: Molecular epidemiology and genetic history of European-type genotype 3 hepatitis $\mathrm{E}$ virus indigenized in the central region of Japan. Infect Genet Evol 2012;12:1524-1534.

90 Nakano T, Takahashi K, Pybus OG, et al: New findings regarding the epidemic history and population dynamics of Japan-indigenous genotype 3 hepatitis $\mathrm{E}$ virus inferred by molecular evolution. Liver Int 2012;32: 675-688.

91 Takahashi K, Kitajima N, Abe N, Mishiro S: Complete or near-complete nucleotide sequences of hepatitis $\mathrm{E}$ virus genome recovered from a wild boar, a deer, and four patients who ate the deer. Virology 2004;330: 501-505.

92 Zheng Y, Ge S, Zhang J, et al: Swine as a principal reservoir of hepatitis $\mathrm{E}$ virus that infects humans in eastern China. J Infect Dis 2006;193:1643-1649.

93 Liu P, Li L, Wang L, et al: Phylogenetic analysis of 626 hepatitis $\mathrm{E}$ virus (HEV) isolates from humans and animals in China (1986-2011) showing genotype diversity and zoonotic transmission. Infect Genet Evol 2012;12: 428-434.

94 Yazaki Y, Mizuo H, Takahashi M, et al: Sporadic acute or fulminant hepatitis $\mathrm{E}$ in Hokkaido, Japan, may be food-borne, as suggested by the presence of hepatitis $\mathrm{E}$ virus in pig liver as food. J Gen Virol 2003;84:23512357.

95 Clemente-Casares P, Pina S, Buti M, et al: Hepatitis E virus epidemiology in industrialized countries. Emerg Infect Dis 2003;9:448-454.

96 Crossan C, Baker PJ, Craft J, Takeuchi Y, Dalton HR, Scobie L: Hepatitis E virus genotype 3 in shellfish, United Kingdom. Emerg Infect Dis 2012;18:2085-2087. 
97 Yugo DM, Meng XJ: Hepatitis E virus: foodborne, waterborne and zoonotic transmission. Int J Environ Res Public Health 2013;10:4507-4533.

98 Kokkinos P, Kozyra I, Lazic S, et al: Harmonised investigation of the occurrence of human enteric viruses in the leafy green vegetable supply chain in three European countries. Food Environ Virol 2012;4:179-191.

99 Faber MS, Wenzel JJ, Jilg W, Thamm M, Höhle M, Stark K: Hepatitis E virus seroprevalence among adults, Germany. Emerg Infect Dis 2012;18:1654-1657.

100 Robert Koch-Institut: SurvStat @ RKI 2.0. https:// survstat.rki.de/Content/Query/Create.aspx (last accessed May 7, 2015)

101 Hakze-van der Honing RW, van Coillie E, Antonis AFG, van der Poel WHM: First isolation of hepatitis E virus genotype 4 in Europe through swine surveillance in the Netherlands and Belgium. PLoS ONE 2011; 6:e22673.

102 Colson P, Romanet P, Moal V, et al: Autochthonous infections with hepatitis E virus genotype 4, France. Emerg Infect Dis 2012;18:1361-1364.

103 Garbuglia AR, Scognamiglio P, Petrosillo N, et al: Hepatitis $\mathrm{E}$ virus genotype 4 outbreak, Italy, 2011. Emerg Infect Dis 2013;19:110-114

104 Monne I, Ceglie L, Di Martino G, et al: Hepatitis E virus genotype 4 in a pig farm, Italy, 2013. Epidemiol Infect 2015;143:529-533.

105 Colson P, Swiader L, Motte A, Ferretti A, Borentain P, Gerolami R: Circulation of almost genetically identical hepatitis E virus of genotype 4 in France. J Clin Virol 2012;55:181-183.

106 Bouamra Y, Gérolami R, Arzouni JP, et al: Emergence of autochthonous infections with hepatitis $\mathrm{E}$ virus of genotype 4 in Europe. Intervirology 2014;57:43-48.

107 Tessé S, Lioure B, Fornecker L, et al: Circulation of genotype 4 hepatitis $\mathrm{E}$ virus in Europe: first autochthonous hepatitis E infection in France. J Clin Virol 2012; 54:197-200.

108 Cooper K, Huang FF, Batista L, et al: Identification of genotype 3 hepatitis $\mathrm{E}$ virus (HEV) in serum and fecal samples from pigs in Thailand and Mexico, where genotype 1 and $2 \mathrm{HEV}$ strains are prevalent in the respective human populations. J Clin Microbiol 2005;43: 1684-1688.

109 Purcell RH, Emerson SU: Hepatitis E: an emerging awareness of an old disease. J Hepatol 2008;48:494503.

110 Adlhoch C, Wolf A, Meisel H, Kaiser M, Ellerbrok H, Pauli G: High HEV presence in four different wild boar populations in East and West Germany. Vet Microbiol 2009;139:270-278.

111 Zhu YM, Dong SJ, Si FS, et al: Swine and human hepatitis E virus (HEV) infection in China. J Clin Virol 2011;52:155-157.

112 Geng J, Wang L, Wang X, et al: Potential risk of zoonotic transmission from young swine to human: seroepidemiological and genetic characterization of hepatitis $\mathrm{E}$ virus in human and various animals in Beijing, China. J Viral Hepat 2011;18:e583-590.

113 Geng JB, Wang MR, Wang L, et al: Genetic characteristics and pathogenicity of human hepatitis $\mathrm{E}$ virus in Nanjing, China. World J Gastroenterol 2012;18:965970.

114 Wang H, He Y, Shen Q, et al: Complete genome sequence of the genotype 4 hepatitis $\mathrm{E}$ virus strain prevalent in swine in Jiangsu Province, China, reveals a close relationship with that from the human population in this area. J Virol 2012;86:8334-8335.

115 Colson P, Borentain P, Queyriaux B, et al: Pig liver sausage as a source of hepatitis $\mathrm{E}$ virus transmission to humans. J Infect Dis 2010;202:825-834.

116 Berto A, Grierson S, Hakze-van der Honing R, et al: Hepatitis E virus in pork liver sausage, France. Emerg Infect Dis 2013;19:264-266.
117 Geng Y, Wang C, Zhao C, et al: Serological prevalence of hepatitis $\mathrm{E}$ virus in domestic animals and diversity of genotype 4 hepatitis E virus in China. Vector Borne Zoonotic Dis 2010;10:765-770.

118 Berto A, Backer JA, Mesquita JR, et al: Prevalence and transmission of hepatitis $\mathrm{E}$ virus in domestic swine populations in different European countries. BMC Res Notes 2012;5:190.

119 Baechlein C: Hepatitis E virus in German domestic pigs: occurrence and prevalence. Thesis, Institute of Virology, Department of Infectious Diseases, University of Veterinary Medicine Hannover. Gießen, DVG Service, 2011. http://elib.tiho-hannover.de/dissertations/baechleinc_ws11.pdf(last accessed May 7, 2015).

120 Wacheck S, Werres C, Mohn U, et al: Detection of IgM and IgG against hepatitis $\mathrm{E}$ virus in serum and meat juice samples from pigs at slaughter in Bavaria, Germany. Foodborne Pathog Dis 2012;9:655-660.

121 Purcell RH, Emerson SU: Hidden danger: the raw facts about hepatitis E virus. J Infect Dis 2010;202:819-821.

122 Berto A, Martelli F, Grierson S, Banks M: Hepatitis E virus in pork food chain, United Kingdom, 2009-2010. Emerg Infect Dis 2012;18:1358-1360.

123 Di Bartolo I, Diez-Valcarce M, Vasickova P, et al: Hepatitis $\mathrm{E}$ virus in pork production chain in Czech Republic, Italy, and Spain, 2010. Emerg Infect Dis 2012; 18:1282-1289.

124 Wenzel JJ, Preiss J, Schemmerer M, Huber B, Jilg W: Test performance characteristics of anti-HEV IgG assays strongly influence hepatitis E seroprevalence estimates. J Infect Dis 2013;207:497-500.

125 Martinelli N, Pavoni E, Filogari D, et al: Hepatitis E virus in wild boar in the central northern part of Italy. Transbound Emerg Dis 2015;62:217-222.

126 Schielke A, Sachs K, Lierz M, Appel B, Jansen A, Johne $\mathrm{R}$ : Detection of hepatitis $\mathrm{E}$ virus in wild boars of rural and urban regions in Germany and whole genome characterization of an endemic strain. Virol J 2009;6: 58.

127 Izopet J, Dubois M, Bertagnoli S, et al: Hepatitis E virus strains in rabbits and evidence of a closely related strain in humans, France. Emerg Infect Dis 2012;18: 1274-1281.

128 Geng Y, Zhao C, Song A, et al: The serological prevalence and genetic diversity of hepatitis $\mathrm{E}$ virus in farmed rabbits in China. Infect Genet Evol 2011;11: $476-482$.

129 Cossaboom CM, Córdoba L, Cao D, Ni YY, Meng XJ: Complete genome sequence of hepatitis $\mathrm{E}$ virus from rabbits in the United States. J Virol 2012;86:1312413125.

130 Jirintai S, Jinshan, Tanggis, et al: Molecular analysis of hepatitis E virus from farm rabbits in Inner Mongolia, China and its successful propagation in A549 and PLC/PRF/5 cells. Virus Res 2012;170:126-137.

131 Liu P, Bu QN, Wang L, et al: Transmission of hepatitis $\mathrm{E}$ virus from rabbits to cynomolgus macaques. Emerg Infect Dis 2013; 19:559-565

132 Johne R, Plenge-Bonig A, Hess M, Ulrich RG, Reetz J, Schielke A: Detection of a novel hepatitis E-like virus in faeces of wild rats using a nested broad-spectrum RT-PCR. J Gen Virol 2010;91:750-758.

133 Purcell RH, Engle RE, Rood MP, et al: Hepatitis E virus in rats, Los Angeles, California, USA. Emerg Infect Dis 2011;17:2216-2222.

134 Mulyanto, Depamede SN, Sriasih M, et al: Frequent detection and characterization of hepatitis $\mathrm{E}$ virus variants in wild rats (Rattus rattus) in Indonesia. Arch Virol 2013;158:87-96.

135 Dremsek P, Wenzel JJ, Johne R, et al: Seroprevalence study in forestry workers from eastern Germany using novel genotype 3- and rat hepatitis E virus-specific immunoglobulin G ELISAs. Med Microbiol Immunol 2012;20:189-200.
136 Jirintai S, Tanggis, Mulyanto, et al: Rat hepatitis E virus derived from wild rats (Rattus rattus) propagates efficiently in human hepatoma cell lines. Virus Res 2014; 185:92-102.

137 Lack JB, Volk K, Van Den Bussche RA: Hepatitis E virus genotype 3 in wild rats, United States. Emerg Infect Dis 2012;18:1268-1273.

138 Kanai Y, Miyasaka S, Uyama S, et al: Hepatitis E virus in Norway rats (Rattus norvegicus) captured around a pig farm. BMC Res Notes 2012;5:4.

139 Saad MD, Hussein HA, Bashandy MM, et al: Hepatitis E virus infection in work horses in Egypt. Infect Genet Evol 2007;7:368-373.

140 Payne CJ, Ellis TM, Plant SL, Gregory AR, Wilcox GE Sequence data suggests big liver and spleen disease virus (BLSV) is genetically related to hepatitis $\mathrm{E}$ virus. Vet Microbiol 1999;68:119-125.

141 Haqshenas G, Shivaprasad HL, Woolcock PR, Read DH, Meng XJ: Genetic identification and characterization of a novel virus related to human hepatitis $\mathrm{E}$ virus from chickens with hepatitis-splenomegaly syndrome in the United States. J Gen Virol 2001;82:2449-2462.

142 Meng XJ: From barnyard to food table: the omnipresence of hepatitis $\mathrm{E}$ virus and risk for zoonotic infection and food safety. Virus Res 2011;161:23-30.

143 Bányai K, Tóth ÁG, Ivanics É, Glávits R, SzentpáliGavallér K, Dán Á: Putative novel genotype of avian hepatitis E virus, Hungary, 2010. Emerg Infect Dis 2012;18:1365-1368.

144 Raj VS, Smits SL, Pas SD, et al: Novel hepatitis E virus in ferrets, the Netherlands. Emerg Infect Dis 2012;18 1369-1370.

145 Woo PC, Lau SK, Teng JL, et al: New hepatitis E virus genotype in camels, the Middle East. Emerg Infect Dis 2014;20:1044-1048.

146 Nagashima S, Takahashi M, Jirintai S, et al: A PSAP motif in the ORF3 protein of hepatitis $E$ virus is necessary for virion release from infected cells. J Gen Virol 2011;92:269-278.

147 Okamoto H: Culture systems for hepatitis E virus. J Gastroenterol 2013;48:147-158.

148 Rogée S, Talbot N, Caperna T, Bouquet J, Barnaud E, Pavio N: New models of hepatitis $\mathrm{E}$ virus replication in human and porcine hepatocyte 1 cell line. J Gen Virol 2013;94:549-558.

149 Abravanel F, Sandres-Saune K, Lhomme S, Dubois M, Mansuy JM, Izopet J: Genotype 3 diversity and quantification of hepatitis E virus RNA. J Clin Microbiol 2012;50:897-902.

150 Baylis SA, Hanschmann KM, Blümel J, Nübling CM; HEV Collaborative Study Group: Standardization of hepatitis $\mathrm{E}$ virus (HEV) nucleic acid amplification technique-based assays: an initial study to evaluate a panel of HEV strains and investigate laboratory performance. J Clin Microbiol 2011;49:1234-1239.

151 Mokhtari C, Marchadier E, Haïm-Boukobza S, et al Comparison of real-time RT-PCR assays for hepatitis E virus RNA detection. J Clin Virol 2013;58:36-40.

152 Baylis SA, Blümel J, Mizusawa S, et al; HEV Collaborative Study Group: World Health Organization international standard to harmonize assays for detection of hepatitis E virus RNA. Emerg Infect Dis 2013;19:729735

153 Kamar N, Bendall R, Legrand-Abravanel F, et al: Hepatitis E. Lancet 2012;379:2477-2488.

154 Khudyakov Y, Kamili S: Serological diagnostics of hepatitis E virus infection. Virus Res 2011;161:84-92.

$155 \mathrm{Ma} \mathrm{H}$, Song X, Harrison TJ, Zhang H, Huang W, Wang Y: Hepatitis E virus ORF3 antigens derived from genotype 1 and 4 viruses are detected with varying efficiencies by an anti-HEV enzyme immunoassay. J Med Virol 2011;83:827-832. 
156 Bendall R, Ellis V, Ijaz S, Ali R, Dalton H: A comparison of two commercially available anti-HEV IgG kits and a re-evaluation of anti-HEV IgG seroprevalence data in developed countries. J Med Virol 2010;82:799_ 805.

157 Rossi-Tamisier M, Moal V, Gerolami R, Colson P: Discrepancy between anti-hepatitis $\mathrm{E}$ virus immunoglobulin $\mathrm{G}$ prevalence assessed by two assays in kidney and liver transplant recipients. J Clin Virol 2013;56:62-64.

158 Herremans M, Bakker J, Duizer E, Vennema H, Koopmans MP: Use of serological assays for diagnosis of hepatitis $\mathrm{E}$ virus genotype 1 and 3 infections in a setting of low endemicity. Clin Vaccine Immunol 2007; 14:562-568.

159 Park HK, Jeong SH, Kim JW, et al: Seroprevalence of anti-hepatitis E virus (HEV) in a Korean population: comparison of two commercial anti-HEV assays. BMC Infect Dis 2012;12:142.

$160 \mathrm{Ma} \mathrm{H}$, Song X, Li Z, et al: Varying abilities of recombinant polypeptides from different regions of hepatitis $\mathrm{E}$ virus ORF2 and ORF3 to detect anti-HEV immunoglobulin M. J Med Virol 2009;81:1052-1061.

161 Drobeniuc J, Meng J, Reuter G, et al: Serologic assays specific to immunoglobulin $\mathrm{M}$ antibodies against hepatitis $\mathrm{E}$ virus: pangenotypic evaluation of performances. Clin Infect Dis 2010;51:e24-e27.

162 Schnegg A, Bürgisser P, André C, et al: An analysis of the benefit of using HEV genotype 3 antigens in detecting anti-HEV IgG in a European population. PLoS One 2013;8:e62980.

163 Lewis HC, Wichmann O, Duizer E: Transmission routes and risk factors for autochthonous hepatitis $\mathrm{E}$ virus infection in Europe: a systematic review. Epidemiol Infect 2010;138:145-166.

164 Gupta E, Pandey P, Pandey S, Sharma MK, Sarin SK Role of hepatitis $\mathrm{E}$ virus antigen in confirming active viral replication in patients with acute viral hepatitis $\mathrm{E}$ infection. J Clin Virol 2013;58:374-377.

165 Vollmer T, Knabbe C, Dreier J: Comparison of realtime PCR and antigen assays for detection of hepatitis E virus in blood donors. J Clin Microbiol 2014;52: 2150-2156.

166 Mao J, Zhao Y, She R, et al: Detection and localization of rabbit hepatitis $\mathrm{E}$ virus and antigen in systemic tissues from experimentally intraperitoneally infected rabbits. PLoS One 2014;9:e88607.

167 Majumdar M, Singh MP, Pujhari SK, Bhatia D, Chawla $\mathrm{Y}$, Ratho RK: Hepatitis E virus antigen detection as an early diagnostic marker: report from India. J Med Virol 2013;85:823-827.

168 Zhang F, Li X, Li Z, et al: Detection of HEV antigen as a novel marker for the diagnosis of hepatitis E. J Med Virol 2006;78:1441-1448.

169 Ritter A, Witteler H, Simpson B, et al: A multi-centre study of HEV seropositivity in random blood donors. J Hepatol 1993;18(suppl 1):25.

170 Krumbholz A, Mohn U, Lange J, et al: Prevalence of hepatitis E virus-specific antibodies in humans with occupational exposure to pigs. Med Microbiol Immunol 2012;201:239-244.

171 Vollmer T, Diekmann J, Johne R, Eberhardt M, Knabbe C, Dreier J: Novel approach for detection of hepatitis E virus infection in German blood donors. J Clin Microbiol 2012;50:2708-2713.

172 Juhl D, Baylis SA, Blümel J, Görg S, Hennig H: Seroprevalence and incidence of hepatitis $\mathrm{E}$ virus infection in German blood donors. Transfusion 2014;54:49-56.

173 Baylis SA, Nick S, Blümel J, Nübling CM: Hepatitis E virus and blood donors in Germany. Vox Sang 2010; 98:479.

174 Slot E, Hogema BM, Riezebos-Brilman A, Kok TM, Molier M, Zaaijer HL: Silent hepatitis E virus infection in Dutch blood donors, 2011 to 2012. Euro Surveill 2013;18:pii=20550.
175 Fukuda S, Ishikawa M, Ochiai N, et al: Unchanged high prevalence of antibodies to hepatitis $\mathrm{E}$ virus (HEV) and HEV RNA among blood donors with an elevated alanine aminotransferase level in Japan during 1991-2006. Arch Virol 2007;152:1623-1635.

176 Baylis SA, Gärtner T, Nick S, Ovemyr J, Blümel J: Occurrence of hepatitis $\mathrm{E}$ virus RNA in plasma donations from Sweden, Germany and the United States. Vox Sang 2012;103:89-90.

177 Corman VM, Drexler JF, Eckerle I, Roth WK, Drosten C, Eis-Hübinger AM: Zoonotic hepatitis E virus strains in German blood donors. Vox Sang 2013;104:179-180.

178 Ijaz S, Szypulska R, Tettmar KI, et al: Detection of hepatitis $\mathrm{E}$ virus RNA in plasma mini-pools from blood donors in England. Vox Sang 2012;102:272.

179 Baylis SA, Koc O, Nick S, Blümel J: Widespread distribution of hepatitis $\mathrm{E}$ virus in plasma fractionation pools. Vox Sang 2012;102:182-183.

180 Arankalle VA, Chobe LP: Hepatitis E virus: can it be transmitted parenterally? J Viral Hepat 1999;6:161164 .

181 Khuroo MS, Kamili S, Yattoo GN: Hepatitis E virus infection may be transmitted through blood transfusions in an endemic area. J Gastroenterol Hepatol 2004;19: $778-784$.

182 Ibrahim EH, Abdelwahab SF, Nady S, et al: Prevalence of anti-HEV IgM among blood donors in Egypt. Egypt J Immunol 2011;18:47-58.

183 Guo QS, Yan Q, Xiong JH, et al: Prevalence of hepatitis E virus in Chinese blood donors. J Clin Microbiol 2010;48:317-318.

184 Dalton HR, Hunter JG, Bendall RP: Hepatitis E. Curr Opin Infect Dis 2013;26:471-478.

185 Bundesärzekammer: Richtlinien zur Gewinnung von Blut und Blutbestandteilen und zur Anwendung von Blutprodukten (Hämotherapie) - Aufgestellt gemäß $\$ \S$ 12a u. 18 Transfusionsgesetz von der Bundesärztekammer im Einvernehmen mit dem Paul-Ehrlich-Institut (Zweite Richtlinienanpassung 2010). 2010. www.bundesaerztekammer.de/downloads/RiliHaemotherapie2010.pdf (last accessed May 7, 2015).

186 Burger R, Gerlich W, Gürtler L, et al: Hepatitis A virus. Transfus Med Hemother 2005;32:167-173

187 Féray C, Pawlotsky JM, Roque-Afonso AM, Samuel D, Dhumeaux D: Should we screen blood products for hepatitis E virus RNA? Lancet 2014;383:218.

188 Matsubayashi K, Nagaoka Y, Sakata H, et al: Transfusion-transmitted hepatitis $\mathrm{E}$ caused by apparently indigenous hepatitis E virus strain in Hokkaido, Japan. Transfusion 2004;44:934-940.

189 Matsubayashi K, Kang JH, Sakata H, et al: A case of transfusion-transmitted hepatitis E caused by blood from a donor infected with hepatitis $\mathrm{E}$ virus via zoonotic food-borne route. Transfusion 2008;48:13681375.

190 Mitsui T, Tsukamoto Y, Yamazaki C, et al: Prevalence of hepatitis $\mathrm{E}$ virus infection among hemodialysis patients in Japan: evidence for infection with a genotype 3 HEV by blood transfusion. J Med Virol 2004;74: 563-572.

191 Boxall E, Herborn A, Kochethu G, et al: Transfusiontransmitted hepatitis $\mathrm{E}$ in a 'nonhyperendemic' country. Transfus Med 2006;16:79-83.

192 Colson P, Coze C, Gallian P, Henry M, De Micco P, Tamalet C: Transfusion-associated hepatitis E, France. Emerg Infect Dis 2007;13:648-649.

193 Huzly D, Umhau M, Bettinger D, et al: Transfusiontransmitted hepatitis E in Germany, 2013. Euro Surveill 2014;19:pii=20812.

194 Bettinger D, Schorb E, Huzly D, et al: Chronic hepatitis E virus infection following allogeneic hematopoietic stem cell transplantation: an important differential diagnosis for graft versus host disease. Ann Hematol 2014;94:359-360
195 Harrison A, Scobie L, Crossan C, et al: Hepatitis E seroprevalence in recipients of renal transplants or haemodialysis in southwest England: a case-control study. J Med Virol 2013;85:266-271.

196 Barzilai A, Schulman S, Karetnyi YV, et al: Hepatitis E virus infection in hemophiliacs. J Med Virol 1995;46: 153-156.

197 Zaaijer HL, Mauser-Bunschoten EP, ten Veen JH, et al: Hepatitis $\mathrm{E}$ virus antibodies among patients with hemophilia, blood donors, and hepatitis patients. J Med Virol 1995;46:244-246.

198 Toyoda H, Honda T, Hayashi K, et al: Prevalence of hepatitis E virus $\operatorname{IgG}$ antibody in Japanese patients with hemophilia. Intervirology 2008;51:21-25.

199 Andonov A, Rock G, Lin L, et al; Members of the Canadian Apheresis Group (CAG): Serological and molecular evidence of a plausible transmission of hepatitis E virus through pooled plasma. Vox Sang 2014;107:213-219.

200 Agence nationale de sécurité du médicament et des produits de santé: Rapport d'activité d'hémovigilance 2012. 2014. http://ansm.sante.fr/var/ansm site/storage/ original/application/b893629101bd8fdb10d446fabf 34768b.pdf (last accessed May 7, 2015).

201 Hauser L, Roque-Afonso AM, Beylouné A, et al: Hepatitis $\mathrm{E}$ transmission by transfusion of Intercept blood system-treated plasma. Blood 2014;123:796-797.

202 Kamar N, Selves J, Mansuy JM, et al: Hepatitis E virus and chronic hepatitis in organ-transplant recipients. N Engl J Med 2008;358:811-817.

203 Kamar N, Rostaing L, Izopet J: Hepatitis E virus infection in immunosuppressed patients: natural history and therapy. Semin Liver Dis 2013;33:62-70.

204 Kamar N, Legrand-Abravanel F, Izopet J, Rostaing L: Hepatitis E virus: what transplant physicians should know. Am J Transplant 2012;12:2281-2287.

205 Balayan MS, Fedorova OE, Mikhailov MI, et al: Antibody to hepatitis $\mathrm{E}$ virus in HIV-infected individuals and AIDS patients. J Viral Hepat 1997;4:279-283.

206 Abravanel F, Lhomme S, Chapuy-Regaud S, et al: Hepatitis $\mathrm{E}$ virus reinfections in solid-organ-transplant recipients can evolve into chronic infections. J Infect Dis 2014;209:1900-1906.

207 Crum-Cianflone NF, Curry J, Drobeniuc J, et al; Infectious Disease Clinical Research Program HIV Working Group: Hepatitis E virus infection in HIV-infected persons. Emerg Infect Dis 2012;18:502-506.

208 Moal V, Legris T, Burtey S, et al: Infection with hepatitis $\mathrm{E}$ virus in kidney transplant recipients in southeastern France. J Med Virol 2013;85:462-471.

209 Pischke S, Hardtke S, Bode U, et al: Ribavirin treatment of acute and chronic hepatitis E: a single-centre experience. Liver Int 2013;33:722-726.

210 Gerolami R, Borentain P, Raissouni F, Motte A, Solas C, Colson P: Treatment of severe acute hepatitis E by ribavirin. J Clin Virol 2011;52:60-62.

211 Zhu FC, Zhang J, Zhang XF, et al: Efficacy and safety of a recombinant hepatitis $\mathrm{E}$ vaccine in healthy adults: a large-scale, randomised, double-blind placebo-controlled, phase 3 trial. Lancet 2010;376:895-902.

212 Wu T, Li SW, Zhang J, Ng MH, Xia NS, Zhao Q: Hepatitis $\mathrm{E}$ vaccine development: a 14 year odyssey. Hum Vaccin Immunother 2012;8:823-827.

213 Shrestha MP, Scott RM, Joshi DM, et al: Safety and efficacy of a recombinant hepatitis $\mathrm{E}$ vaccine. N Engl J Med 2007;356:895-903.

214 Deshmukh TM, Lole KS, Tripathy AS, Arankalle VA: Immunogenicity of candidate hepatitis $\mathrm{E}$ virus DNA vaccine expressing complete and truncated ORF2 in mice. Vaccine 2007;25:4350-4360.

215 Kamili S: Toward the development of a hepatitis E vaccine. Virus Res 2011;161:93-100.

216 Cheng X, Wang S, Dai X, et al: Rabbit as a novel animal model for hepatitis $E$ virus infection and vaccine evaluation. PLoS ONE 2012;7:e51616. 
217 Arankalle VA, Chobe LP: Retrospective analysis of blood transfusion recipients: Evidence for post-transfusion hepatitis E. Vox Sang 2000;79:72-74.

218 Hewitt PE, Ijaz S, Brailsford SR, et al: Hepatitis E virus in blood components: a prevalence and transmission study in southeast England. Lancet 2014;384:17661773.

219 Dreier J, Juhl D: Autochthonous hepatitis E virus infections: a new transfusion-associated risk? Transfus Med Hemother 2014;41:29-39.
220 Laperche S, Izopet J, Lefrère JJ: Safety measures to prevent hepatitis $\mathrm{E}$ virus transmission by blood transfusion. Transfusion 2014;54:2134-2135.

221 Kumar S, Subhadra S, Singh B, Panda BK: Hepatitis E virus: the current scenario. Int J Infect Dis 2013; 17:e228-23.

222 Owada T, Kaneko M, Matsumoto C, et al: Establishment of culture systems for genotypes 3 and 4 hepatitis E virus (HEV) obtained from human blood, and application of HEV inactivation using a pathogen-reduction technology (PRT) system. Transfusion 2014;54: 2820-2827.
223 Yunoki M, Yamamoto S, Tanaka H, et al: Extent of hepatitis $\mathrm{E}$ virus elimination is affected by stabilizers present in plasma products and pore size of nanofilters. Vox Sang 2008;95:94-100.

224 Sakai K, Yunoki M: Significant inactivation and/or removal of non-enveloped viruses and prions during the manufacturing process of albumin preparation. Poster PDA Virus \& TSE Conference, Berlin, June 4-6, 2013.

225 Modrow S, Wenzel JJ, Schimanski S, et al: No HEV sequences were detected in currently manufactured concentrates on the German market. Vox Sang 2011;100: 351-358. 